\title{
The Seismic Response of High-Speed Railway Bridges Subjected to Near-Fault Forward Directivity Ground Motions Using a Vehicle-Track-Bridge Element
}

\author{
Chen Ling-kun, ${ }^{1,2}$ Jiang Li-zhong, ${ }^{2,3}$ Guo Wei,, ${ }^{2,3}$ Liu Wen-shuo,, \\ Zeng Zhi-ping, ${ }^{2,3}$ and Chen Ge-wei ${ }^{4}$ \\ ${ }^{1}$ College of Civil Science and Engineering, Yangzhou University, Yangzhou 225127, China \\ ${ }^{2}$ National Engineering Laboratory for High-Speed Railway Construction, Central South University, Changsha 410075, China \\ ${ }^{3}$ School of Civil Engineering, Central South University, Changsha 410075, China \\ ${ }^{4}$ Department of Civil and Engineering, University of Auckland, Auckland 1142, New Zealand
}

Correspondence should be addressed to Chen Ling-kun; lingkunchen08@hotmail.com

Received 15 July 2013; Accepted 1 November 2013; Published 27 February 2014

Academic Editor: Vadim V. Silberschmidt

Copyright (C) 2014 Chen Ling-kun et al. This is an open access article distributed under the Creative Commons Attribution License, which permits unrestricted use, distribution, and reproduction in any medium, provided the original work is properly cited.

\begin{abstract}
Based on the Next Generation Attenuation (NGA) project ground motion library, the finite element model of the high-speed railway vehicle-bridge system is established. The model was specifically developed for such system that is subjected to near-fault ground motions. In addition, it accounted for the influence of the rail irregularities. The vehicle-track-bridge (VTB) element is presented to simulate the interaction between train and bridge, in which a train can be modeled as a series of sprung masses concentrated at the axle positions. For the short period railway bridge, the results from the case study demonstrate that directivity pulse effect tends to increase the seismic responses of the bridge compared with far-fault ground motions or nonpulse-like motions and the directivity pulse effect and high values of the vertical acceleration component can notably influence the hysteretic behaviour of piers.
\end{abstract}

\section{Introduction}

In principle, when an earthquake fault ruptures and propagates towards a site at a speed close to the shear wave velocity, the generated waves will arrive at the site at approximately the same time. This creates the cumulative effect of almost all of the seismic energy radiation from fault and generates a "distinct" velocity pulse within the ground motion time history, at a strike-normal direction [1].

Figure 1 portrays the three zones of directivity. The circle representing the epicenter and the black line indicates the fault. According to the model, site B (Figure 2) would experience a longer interval of the time interval between the arrivals of the waves; thus, the record at site B would have a long duration but not a velocity pulse. Intense velocity pulse usually occurs at the beginning of a record. Its occurrence is referred to as the FD effect. For more than a decade, the FD effect has been known to have potential to cause severe damage in a structure and in turn cause relatively severe elastic and inelastic responses in structures during certain periods. Figure 3 illustrates ground acceleration, velocity, and displacement time-history traces for the fault-normal component of a typical near-fault ground motion with FD (Northridge 1994 Rinaldi Receiving Station). As indicated particularly by the velocity and displacement traces, the record contains a large pulse within the time range from about 2 to $3 \mathrm{sec}$. To further comparison, a nonpulse record from the Northridge 1994, Century City CC North is also shown.

Rupture directivity has been long recognized since Benioff [2] and Kasahara [3]. In the recordings of large earthquakes and further, it has been theoretically explained by early kinematic models of line sources by Haskell [4], Ben-Menahem [5] who introduced the rupture directivity coefficient of $C_{d}$. This effect has been observed on strong ground motion records in the near-fault region, for instance, 


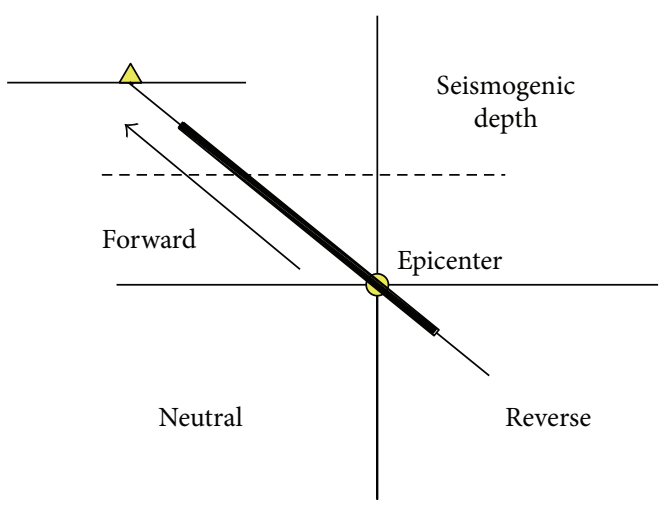

FIgURE 1: Zone of directivity.

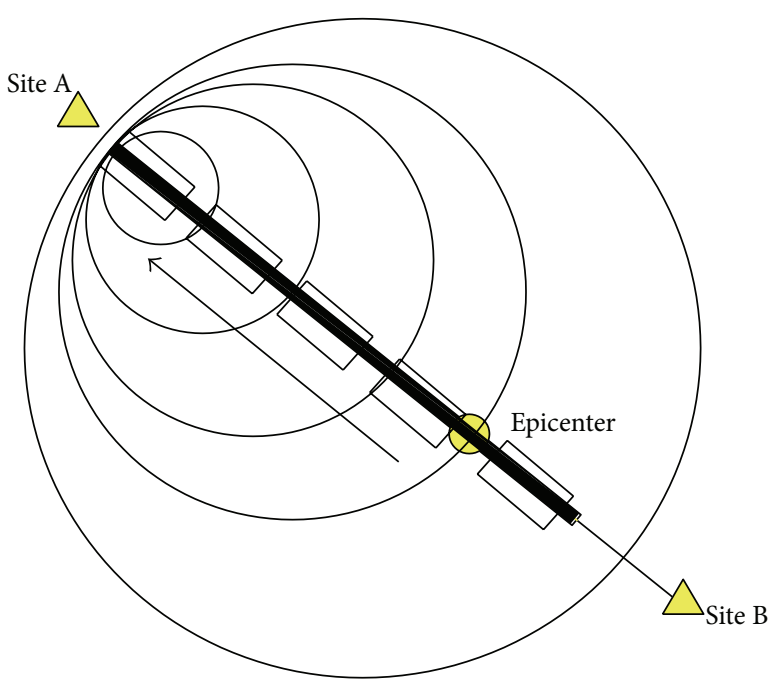

Figure 2: An example of FD effect on Site A.

as the $M_{W} 6.61971$ San Fernando earthquake [6], the $M_{W}$ 6.61979 Emperial valley earthquake [7], the $M_{W} 6.71994$ Northridge earthquake [8], the $M_{W} 7.21995$ HyogokenNanbu (Kobe) earthquake [9], the $M_{W} 7.61999$ Chi-Chi, Taiwan earthquake [10], and $M_{W} 7.41999$ Kocaeli earthquake [11].

Ground motions with a pulse at the beginning of the velocity time history belong to a special class of ground motion that causes severe damage in structures. This class of ground motions, which are indicated by the presence of a velocity pulse, can cause large responses in structures. The influence of near-fault pulse-like ground motions on the seismic response of structure has become a very important topic to lots of researchers in recently years. Alavi and Krawinkler [12] studied the response spectrum pulse as would earthquakes with the FD effect be studied. It was stated that the velocity effect could greatly influence the nonlinear response of the structure. Choi et al. [13] investigate the near-fault ground motion effects on typical Caltrans bridge columns to develop practical and proven bridge design guidelines that incorporate the effects of near-fault ground motions. Mortezaei and Ronagh [14] performed the inelastic time-history analyses to predict the nonlinear behaviour of RC columns that were subjected to both far-fault and near-fault earthquakes, both of which contain a FD effect. MacRae et al. [15] studied the effects of earthquake ground motions on the response of SDOF oscillators with elasticperfectly plastic hysteresis behavior. Tothong and Cornell [16] demonstrated the effectiveness of utilizing advanced ground motion intensity measures to evaluate the seismic performance of a structure subject to near-source ground motions. Baker and Cornell [17] considered a vector-valued intensity measure (IM) to account for the effects of pulselike near-fault ground motions. Xu et al. [18] investigated the application of equivalent pulses to the parameter attenuation relationships developed for near-fault FD motions. Chioccarelli and Iervolino [19] investigated the velocity pulse effect of horizontal components of L'Aquila earthquake. Their research indicated that the vertical components of motion did not provide clear evidence of directivity effects in the rupture-normal direction. Mazza and Vulcano [20] studied the nonlinear dynamic response of an r. c. framed buildings located in a near-fault area, in reference to the horizontal and vertical components of near-fault records. Chen et al. [2124] carried out a series of research on the seismic response of the high-speed railway bridge, discovering some useful 


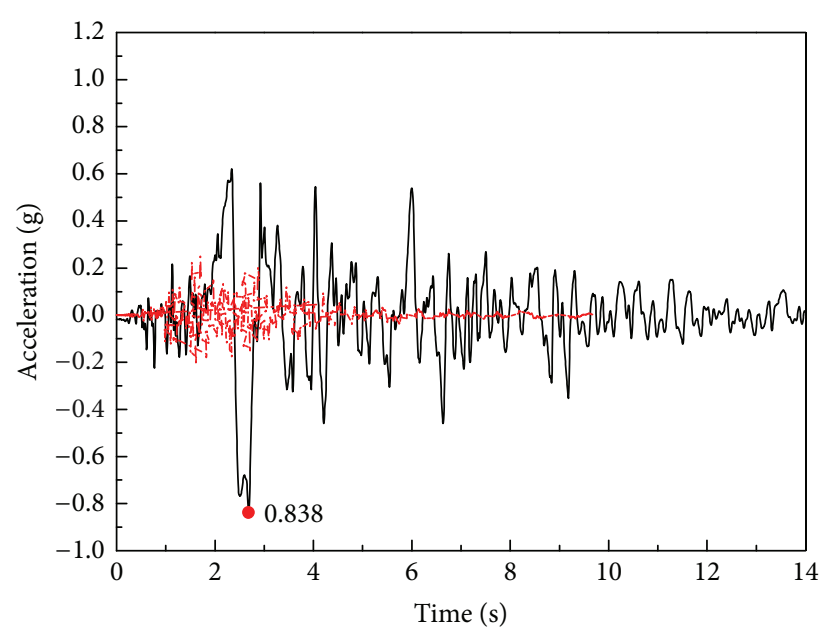

(a) Acceleration time-history curve

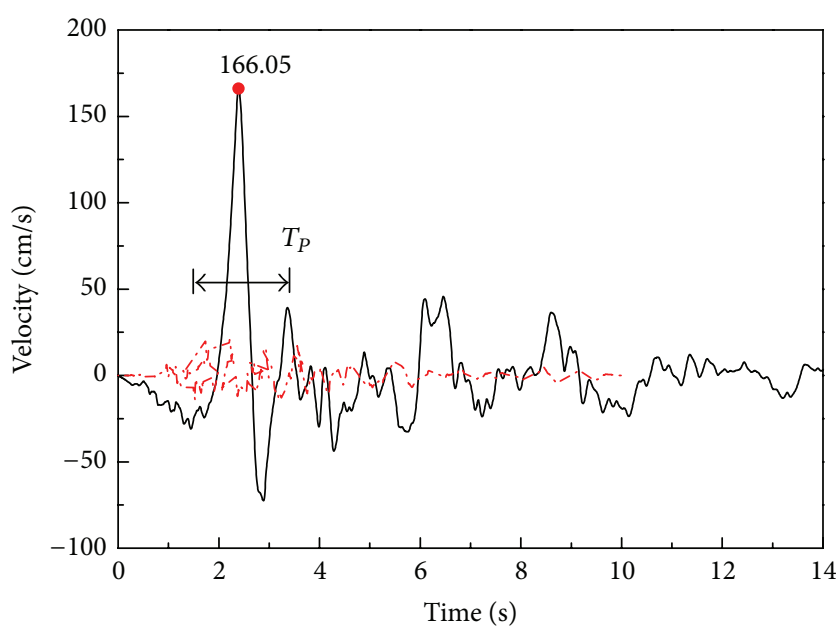

(b) Velocity time-history curve

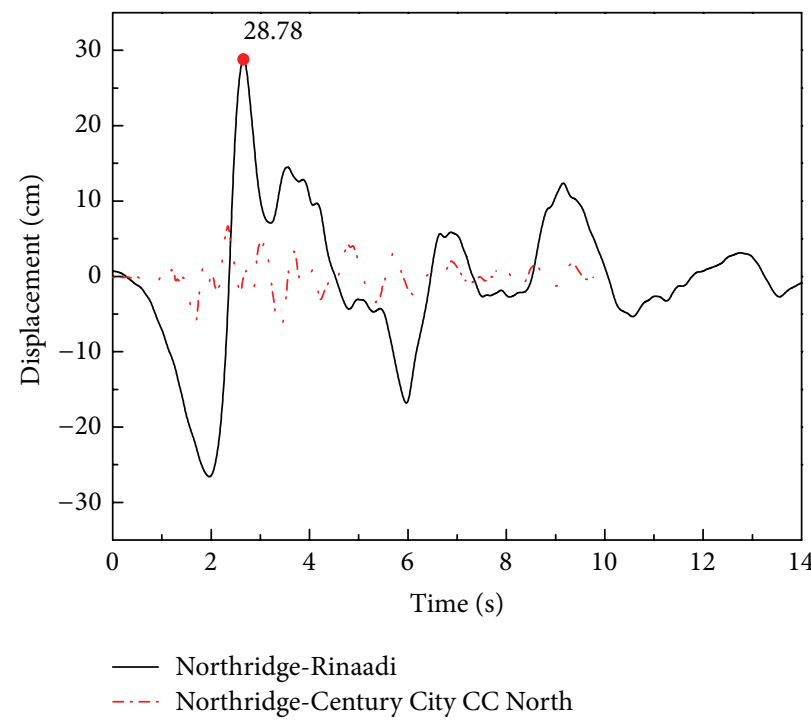

(c) Displacement time-history curve

FIgURE 3: Ground acceleration, velocity, and displacement time histories for record of Northridge Rinaldi and Century City CC North.

conclusions that would assist the seismic design of the railway bridge.

The existing research on the near-fault earthquake focuses mainly on the basic properties and the focal mechanisms. Some research on the seismic dynamic response of the bridge was carried out recently. It concentrated on building structures and highway bridges [25-28], as recommended in recent regulatory design codes and provisions such as ATC-40 (1996) and IBC (ICBO 2000). The site-source and distance-dependent near-source factors $N_{A}$ and $N_{V}$ which consider FD effect were then introduced to amplify the elastic design spectrum and scale the design base shear. There is minimal research on the seismic response of the railway bridge, characterized by the unneglected moving train loading and the ballastless structure above the boxing girder bridge, and most existing railway bridge structures were designed without considering any "near-fault" feature $[29,30]$.
In this paper, a train can be modeled as a series of sprung masses concentrated at the axle positions using the VTB element. The finite element model of the multispan simply supported high-speed railway bridge is set up based on the PEER NAG Strong Ground Motion Database. The seismic performance of short-period high-speed railway bridge under rupture FD pulse-like ground motions was investigated. Furthermore, the rupture FD and high vertical ground motions effects were considered.

\section{Model of Vehicle-Bridge System}

The train loading is one of the dominant factors in the design and the dynamic analysis of the railway bridges. Apart from the simplified design live load pattern of railway bridges in passenger-specific lines, as well as in passenger and freight mixed lines (which were adopted in the general design specifications [31], on the dynamics of bridges under moving 
trains), there are three main types of train models to be used: (1) the moving force model, (2) the moving mass model, and (3) the moving multi-rigid-body system model. Zhang and Xia [32], Gao and Pan [33], Li et al. [34], and Jo et al. [35] modeled the vehicle and the bridge subsystem separately. Yang and $\mathrm{Wu}$ [36] investigate the vibration of simple beams subjected to the passage of high-speed trains, where the train is modeled as a series of sprung masses. By using the modified beam vibration functions as the assumed modes, Cheung et al. [37] analyzed the vibration of multispan nonuniform bridges under a moving train. Although the model cannot realistically predict the response of the vehicle, the model can obtain the closed-form solutions for some problems.

In this study, a global bridge model is developed as shown in Figure 4. The train is traveling over the bridge with a constant speed $v$. It is idealized as a series of lumped masses supported by the suspension systems, as represented by the springs and dashpots, which in turn are acting on the bridge. A train bridge interaction element is presented in when the CRTS II layered slab ballastless track (i.e., China Railway Track System II Type Ballastless Slab Tracks) is introduced to the model based on the existing research $[36,37]$. It consists of a bridge (boxing girder) element and suspension units of the car bodies directly acting on it, as shown in Figure 5, where the rail irregularity $r(x)$ and CRTS II layered slab ballastless track stiffness $k_{B}$ are also indicated. In this model, the column bases are assumed to be rigidly connected to the pile caps, which are in turn assumed to be fully fixed; hence no soil or pile deformation effects are included.

As the model of the VTB element is depicted in Figure 5, a train can be modeled as a series of sprung masses concentrated at the axle positions, of which the suspension device is represented by a spring-dashpot system model, and a bridge as a series of $3 \mathrm{D}$ beam elements. In this study, the notation [ ] is used for a square matrix or a row vector, and \{\} is used for a column vector. The following notation is adopted: $r(x)=$ rail irregularity, $k_{B}=$ ballastless track stiffness, $k_{v}=$ suspension stiffness, $c_{v}=$ suspension damping, $m_{w}=$ wheel mass, and $M_{v}=$ lumped vehicle mass. In addition, the vertical deflections of the wheel and car body masses from the static equilibrium position are denoted as $\{z\}^{T}=\left[z_{W}, z_{M}\right]$ by the generalized coordinates, $z_{w}=$ the vertical displacements of the wheel-sets, and $z_{M}=$ the vertical displacements of the sprung masses, corresponding to the nodal displacements $\{z\}^{T}$, the external forces, $\{p\}^{T}=\left[p_{v}, p_{g}\right]$, where $p_{v}=-\left(M_{v}+\right.$ $\left.m_{w}\right) g, g=$ the acceleration of gravity, and $f_{v g}=$ earthquake loading of the train.

The equations of motion for the vehicle masses in Figure 5 can be written, based on Jo et al. [35] and Xia et al. [38] equations:

$$
\begin{gathered}
{\left[\begin{array}{cc}
m_{w} & 0 \\
0 & M_{v}
\end{array}\right]\left\{\begin{array}{l}
\ddot{z}_{w} \\
\ddot{z}_{M}
\end{array}\right\}+\left[\begin{array}{cc}
c_{v} & -c_{v} \\
-c_{v} & c_{v}
\end{array}\right]\left\{\begin{array}{l}
\dot{z}_{w} \\
\dot{z}_{M}
\end{array}\right\}+\left[\begin{array}{cc}
k_{v} & -k_{v} \\
-k_{v} & k_{v}
\end{array}\right]\left\{\begin{array}{l}
z_{w} \\
z_{M}
\end{array}\right\}} \\
=\left\{\begin{array}{c}
p_{v}+f_{c} \\
-f_{v g}
\end{array}\right\},
\end{gathered}
$$

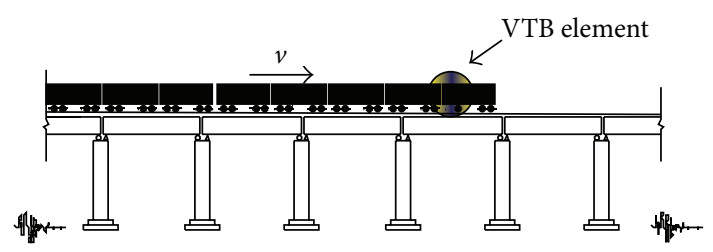

(a) Schematic diagram

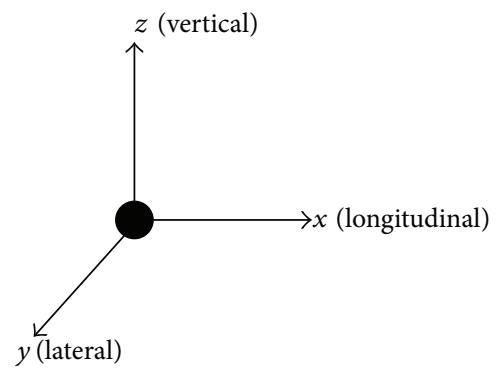

(b) Coordinate law

FIGURE 4: Global model of vehicle-bridge systems.

where $f_{c}$ denotes the interaction force existing between the as wheel-sets and the bridge element. By letting $x_{c}$ denote the position of the contact point and $\left\{N_{c}\right\}$ a vector obtaining the shape functions of the vertical displacement involving the beam evaluated at the contact point $x_{c}$, that is, Hermitian interpolation functions, that is, $\left\{N_{c}\right\}=\left\{N_{i}\left(x_{c}\right)\right\}$, the interaction force can be expressed as

$$
f_{c}=k_{B}\left(\left\{N_{c}\right\}\left[u_{b}\right]+r_{c}-z_{w}\right),
$$

where the condition of $f_{c} \geq 0$ is imposed to exclude the separation of the vehicle from the bridge. In other terms, it $t$ is assumed that the wheel-track interaction obeys the wheeltrack corresponding assumption in the vertical direction; $k_{B}=$ ballast stiffness; the value of $20 \mathrm{MN} / \mathrm{m}$ per rail has been used by Nielsen and Abrahamsson [39], Yau et al. [40] is taken as $40 \mathrm{MN} / \mathrm{m}$ for two rails. CRTS II layered slab ballastless track is used in this study; according to the wheel drop load test $[41], k_{B}=105 \mathrm{kN} / \mathrm{mm} ;\left[u_{b}\right]=$ the nodal displacements of the beam; and $r_{c}=$ the rail irregularity at the contact point $x_{c}$.

The deck of bridge and the piers are idealized as a linear elastic Bernoulli-Euler beam, containing a uniform section. The bridge piers are assumed to remain in the elastic state during the earthquake excitation, which are also assumed to be rigidly fixed at the foundation level. The bridge pier elements can be assembled by conventional procedures, to form the equations of motion for the entire bridge structure. The equations of motion for the bridge element can be written as

$$
\left[m_{b}\right]\left\{\ddot{u}_{b}\right\}+\left[c_{b}\right]\left\{\dot{u}_{b}\right\}+\left[k_{b}\right]\left\{u_{b}\right\}=p_{b}-\left\{N_{c}\right\} f_{c}+f_{b g},
$$

where $\left[m_{b}\right],\left[c_{b}\right]$, and $\left[k_{b}\right]=$ the mass, damping, and stiffness matrices of the bridge element, $p_{b}=$ the external nodal loads, and $f_{b g}=$ the earthquake loading of the bridge. The two factors of Rayleigh damping $c$ (Damping) $=\alpha$ (Mass) + $\beta$ (Stiffness). $\alpha$ and $\beta$ can be given by eigenvalue analysis. 


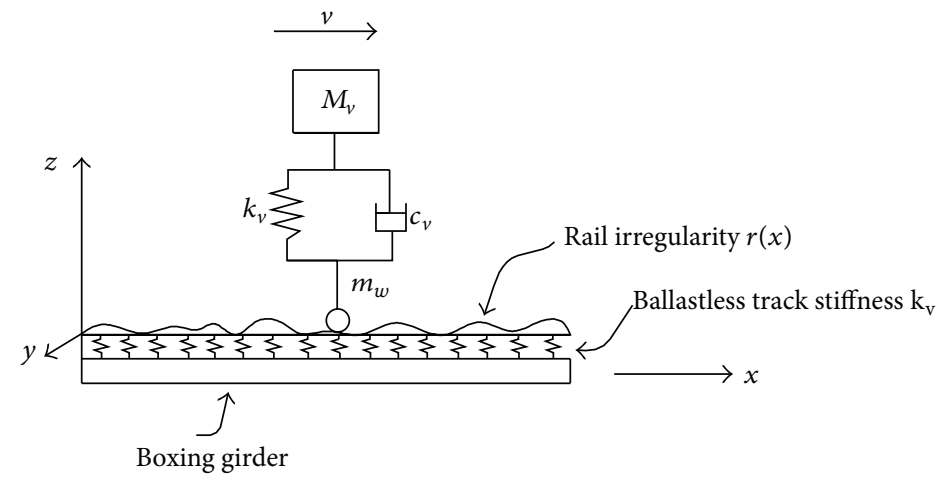

FIgURE 5: Vehicle-track-bridge element.

TABLE 1: Calculation parameters of ICE3.

\begin{tabular}{|c|c|c|c|c|c|c|c|}
\hline \multirow{2}{*}{ Train } & \multicolumn{3}{|c|}{ Mass } & \multicolumn{2}{|c|}{ Stiffness } & \multicolumn{2}{|c|}{ Damping coefficient } \\
\hline & Car body/(kg) & Bogie/(kg) & wheelsets/(kg) & $\begin{array}{c}\text { Primary } \\
\text { suspension } \\
\text { system/(N/m) }\end{array}$ & $\begin{array}{c}\text { Secondary } \\
\text { suspension } \\
\text { system } /(\mathrm{N} / \mathrm{m})\end{array}$ & $\begin{array}{c}\text { Primary } \\
\text { suspension } \\
\text { system } /(\mathrm{N} \cdot \mathrm{s} / \mathrm{m})\end{array}$ & $\begin{array}{c}\text { Secondary } \\
\text { suspension } \\
\text { system } /(\mathrm{N} \cdot \mathrm{s} / \mathrm{m})\end{array}$ \\
\hline Tractor & 48000 & 3200 & 2400 & 1040000 & 400000 & 20000 & 2667000 \\
\hline Trailer & 44000 & 2400 & 2400 & 700000 & 300000 & 20000 & 2667000 \\
\hline
\end{tabular}

TABLE 2: Effective calculation parameters of ICE3.

\begin{tabular}{lcccr}
\hline Train & \multicolumn{2}{c}{$\begin{array}{c}\text { Equivalent mass } \\
\text { Car body and bogie/(kg) }\end{array}$} & Wheelset $/(\mathrm{kg})$ & $\begin{array}{r}\text { Equivalent damping } \\
\text { coefficient }(\mathrm{N} \cdot \mathrm{s} / \mathrm{m})\end{array}$ \\
\hline Tractor & 48888 & 2400 & 289000 & 25981 \\
Trailer & 44721 & 2400 & 210000 & 20470 \\
\hline
\end{tabular}

In analyzing the vehicle-bridge interaction systems, two sets of equations of motion of the second order must be written each for the vehicles and for the bridge. It is the interaction forces existing at the contact points that make the two subsystems coupled. As the contact points move from time to time, the system matrices are, in general, time-dependent and must be updated and factorized at each time step in an incremental analysis. To solve these two sets of equations, procedures of an iterative nature are often adopted [42, 43].

As can be seen from (1) and (3), the vehicle and the bridge interact with each other through the contact force; the system equations as given in (1)-(3) are nonlinear in nature, which can only be solved by incremental methods, with iterations for removing the unbalanced forces. The Wilson- $\theta$ algorithm is used in the step-by-step integration of the combined vehicle and bridge system. Being unconditionally convergent, the method does not require a special step length; the convergence of the generalized displacement of each DOF in both systems must be ensured within the step. In the following case study, the time interval of $0.005 \mathrm{~s}$ is used.

To investigate the seismic response of high-speed railway bridge under a traveling concentrated mass system, the primary and secondary suspension system can be equivalent to the sprung mass system according to the principle of equivalence theory; ICE3 series high-speed vehicle of Germany is employed as vehicle live load. The train traveling over the bridge is assumed to have 14 passenger cars and 2 power cars at the two ends. For simplicity, the train is simulated as a sequence of 32 identical sprung masses. Calculation parameters of ICE3 have been shown in Table 1 [44]. Effective calculation parameters of ICE3 have been shown in Table 2 [45].

\section{Rail Irregularities}

Track irregularities may be caused by factors such as small imperfections in materials, imperfections in manufacturing of rails and rail joints, terrain irregularities, and errors found surveying design and construction. The track irregularity is the distance of the actual position and the theoretical position of the rail, the track irregularity causes the additional velocity and acceleration, the vertical irregularities are considered in this study, and the time domain array sample transformed by German railway spectra of low irregularity is adapted in this paper. In this study, the track irregularity data generated from the German low disturb spectrum is adopted; the power spectrum density is expressed in

$$
S_{v}(\Omega)=\frac{A_{v} \Omega_{c}^{2}}{\left(\Omega^{2}+\Omega_{r}^{2}\right)\left(\Omega^{2}+\Omega_{c}^{2}\right)},
$$


TABLE 3: Characteristic parameter of the power spectral density of German railway low disturb spectrum.

\begin{tabular}{lccc}
\hline $\begin{array}{l}\text { Low disturb spectrum of German } \\
\text { railway }\end{array}$ & $\Omega_{c} /(\mathrm{rad} / \mathrm{m})$ & $\Omega_{r} /(\mathrm{rad} / \mathrm{m})$ & $A_{v} /\left(\mathrm{m}^{2} \cdot \mathrm{rad} / \mathrm{m}\right)$ \\
\hline Parameter & 0.8246 & 0.0206 & $4.032 \times 10^{-7}$ \\
\hline
\end{tabular}

TABLE 4: Properties of near-fault ground motions used in the analyses.

\begin{tabular}{|c|c|c|c|c|c|c|c|c|c|c|c|}
\hline Earthquake & Year & Station & $M_{w}$ & $\begin{array}{l}\text { Dist. } \\
(\mathrm{km})\end{array}$ & Soil & $T_{P}(\mathrm{~s})$ & $\mathrm{PGA}_{H} /(\mathrm{g})$ & $\mathrm{PGV}_{H} /(\mathrm{cm} / \mathrm{s})$ & $\mathrm{PGA}_{V} /(\mathrm{g})$ & $\partial_{\mathrm{PGA}}$ & SF \\
\hline Tabas, Iran/NGA0143 & 1978 & Tabas & 7.3 & 1.79 & Rock & 6.19 & 0.85 & 121.4 & 0.69 & 0.81 & 0.47 \\
\hline $\begin{array}{l}\text { Loma } \\
\text { Prieta/NGA3548 }\end{array}$ & 1989 & $\begin{array}{l}\text { Los Gatos- } \\
\text { Lexington } \\
\text { Dam }\end{array}$ & 6.9 & 3.22 & Stiff soil & 2.40 & 0.44 & 62.1 & 0.15 & 0.34 & 0.91 \\
\hline $\begin{array}{l}\text { Kocaeli, } \\
\text { Turkey/NGA1176 }\end{array}$ & 1999 & Yarimca & 7.5 & 1.38 & Stiff soil & 4.95 & 0.35 & 62.1 & 0.24 & 0.69 & 1.14 \\
\hline Northridge/NGA1044 & 1994 & $\begin{array}{l}\text { Newhall- } \\
\text { Fire } \\
\text { Staion }\end{array}$ & 6.7 & 3.16 & Stiff soil & 1.37 & 0.59 & 97.2 & 0.54 & 0.92 & 0.68 \\
\hline Northridge/NGA1063 & 1994 & Rinaadi & 6.7 & 0.00 & Stiff soil & 1.25 & 0.84 & 166.1 & 0.85 & 1.01 & 0.48 \\
\hline $\begin{array}{l}\text { San } \\
\text { Fernando/NGA0077 }\end{array}$ & 1971 & $\begin{array}{l}\text { Pacoima } \\
\text { Dam }\end{array}$ & 6.6 & 0.00 & Hard rock & 1.64 & 1.23 & 112.5 & 0.57 & 0.46 & 0.33 \\
\hline
\end{tabular}

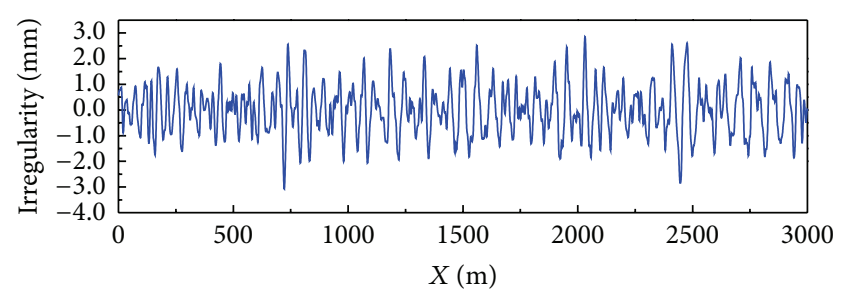

FIGURE 6: Vertical elevation track irregularity sample.

where $S_{v}(\Omega)$ is the vertical irregularities in $S_{v}(\Omega)$ in $\mathrm{m}^{2} /(\mathrm{rad} / \mathrm{m}) . \Omega=$ spatial angular frequency of the irregularity (in $\mathrm{rad} / \mathrm{m}$ ) calculated by $\Omega_{c}=2 \pi / L_{t}$, where $L_{t}$ is the wavelength of the track irregularity, ranging from $1 \mathrm{~m}$ to $80 \mathrm{~m}$, $\Omega_{c}=$ cutoff frequency (in $\mathrm{rad} / \mathrm{m}$ ), $A_{v}=$ roughness constant (in $\mathrm{cm}^{2} \cdot \mathrm{rad} / \mathrm{m}$ ), and $b=0.75 \mathrm{~m}$, the half of the distance of the rolling circle (in $\mathrm{m}$ ).

The time domain array sample transformed by the German railway spectra of low irregularity is adapted. The characteristic parameter of the power spectral density of German railway low disturb spectrum is seen in Table 3. The vertical elevation irregularity is seen in Figure 6.

\section{FD Ground Motion Records}

A set of 6 pulse-like ground motion records with FD effect were chosen to complement the FD database in Table 4 and to therefore evaluate the inelastic seismic response of highspeed railway bridge. These ground motions that can be found in Fu and Menun [46], Akkar et al. [47] Baker [48], and Mazza and Vulcano [49] are mainly recorded on NEHRP soil type B (Rock) and soil type D (stiff soil) conditions [50]. Thus, when a structure in two perpendicular directions is subjected to a near-fault ground motion, the structure in one of the two directions will be subjected to excitations almost as severe as the fault-normal component [51]. For this reason this study focuses on the fault-normal component of nearfault ground motions. From this point forward, the horizontal ground motion components will be referred to as rotated fault normal (FN).

These motions cover a moment magnitude range from 6.6 to 7.5 and a rupture distance (closest distance from site to fault rupture plane) range from 0.0 to $10.0 \mathrm{~km}$; all of the records exhibit velocity pulses. These motions were included because it is clear that they contain FD effects; all of the strong motion records are available in the Pacific Earthquake Engineering Research Center Next Generation Attenuation database (PEER NGA) [52]. The period of the velocity pulse of the near-fault ground motion in Table 4 is quantified from the dominant frequency of the extracted wavelet according to the literature [48].

An important aspect of this study is the comparison of seismic responses at sites in the near-fault regions and to sites that are not influenced by FD effects. Therefore, a second set of far field, nonpulse-like, and non-FD ground motions in Table 5 are also used. The far-field database includes 6 ground motions. Selected records (1) of earthquakes from which FD motions were obtained, for example, Iran Tabas-Ferdows, Kocaeli, Turkey-Ambarli, and Loma Prieta-Cliff House are from the same earthquakes, (2) they are recorded within $90 \mathrm{~km}$ of the ruptured fault, and (3) the same records as those of the 1979 Imperial Valley-Calexico and 1989 Loma PrietaPresidio are listed in the far-fault recordings database in the study referring to the far-fault recordings database in [53].

Strong near-fault ground motions are also characterized by high values of the acceleration ratio $\partial_{\mathrm{PGA}}\left(\partial_{\mathrm{PGA}}=\right.$ $\mathrm{PGA}_{\mathrm{V}} / \mathrm{PGA}_{\mathrm{H}}$ ) defined as the ratio between the peak value of the vertical acceleration, $\mathrm{PGA}_{\mathrm{V}}$, and the analogous value of the horizontal acceleration, $\mathrm{PGA}_{\mathrm{H}}$. As can be seen in 
TABle 5: Properties of far-fault ground motions used in the analyses.

\begin{tabular}{|c|c|c|c|c|c|c|c|c|c|c|}
\hline Earthquake & Year & Station & $M_{w}$ & Dist. $(\mathrm{km})$ & Soil & $\mathrm{PGA}_{H}(\mathrm{~g})$ & $\mathrm{PGV}_{H} /(\mathrm{cm} / \mathrm{s})$ & $\mathrm{PGA}_{V} /(\mathrm{g})$ & $\partial_{\mathrm{PGA}}$ & SF \\
\hline Tabas, Iran/NGA0140 & 1978 & Ferdows & 7.3 & 89.76 & Stiff soil & 0.108 & 8.6 & 0.053 & 0.49 & 3.70 \\
\hline Loma Prieta/NGA0793 & 1989 & Cliff House & 6.9 & 78.58 & Soft rock & 0.108 & 19.8 & 0.062 & 0.57 & 3.70 \\
\hline Kocaeli, Turkey/NGA1147 & 1999 & Ambarli & 7.5 & 68.09 & Soft soil & 0.184 & 33.2 & 0.079 & 0.43 & 2.17 \\
\hline Northridge/NGA0988 & 1994 & Century City CC North & 6.7 & 23.41 & Stiff soil & 0.256 & 21.1 & 0.116 & 0.45 & 1.56 \\
\hline Loma Prieta/NGA0796 & 1989 & Presidio & 6.9 & 77.34 & Soft rock & 0.099 & 12.9 & 0.058 & 0.59 & 4.04 \\
\hline Imperial Valley/NGA0162 & 1979 & Calexico Fire Station & 6.5 & 10.45 & Stiff soil & 0.275 & 21.2 & 0.187 & 0.68 & 1.46 \\
\hline
\end{tabular}

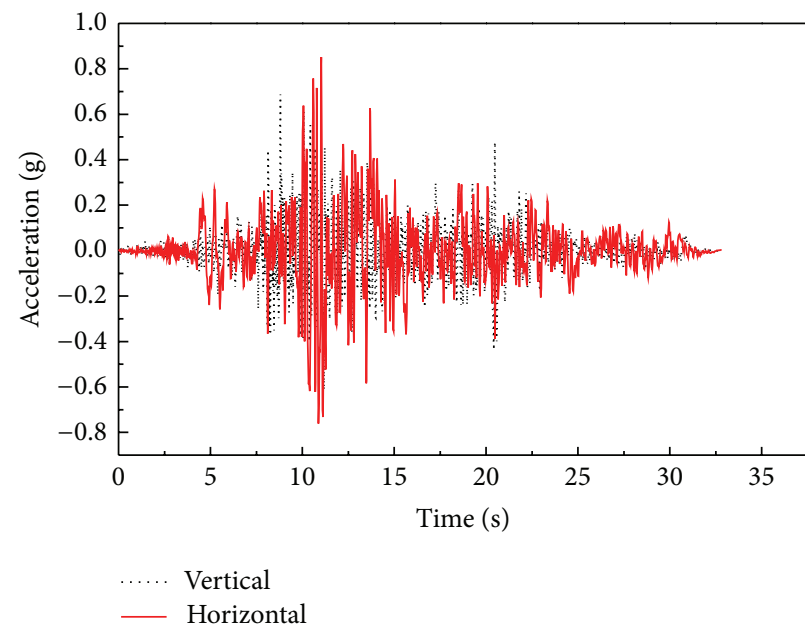

(a) Vertical and horizontal motions of Tabas earthquake, 1978, record from Tabas station

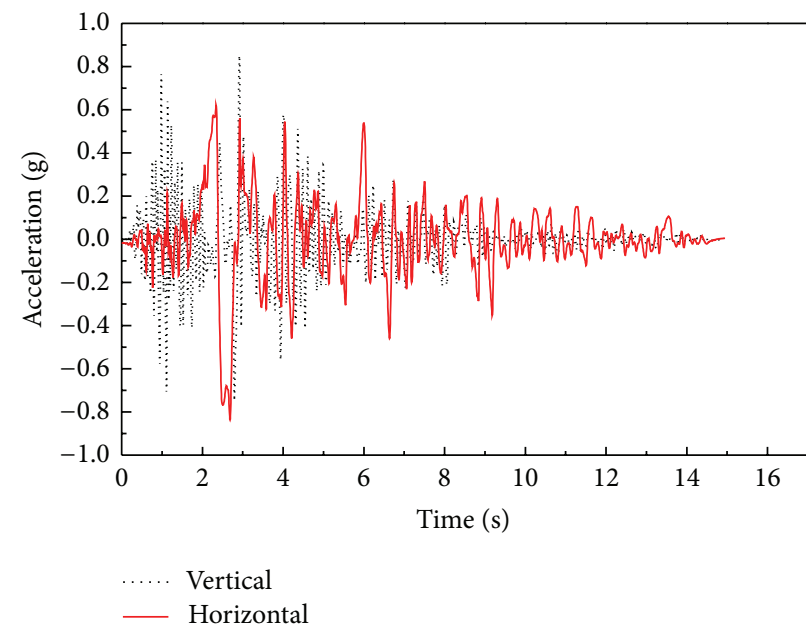

(b) Vertical and horizontal motions of Northridge earthquake, 1978, record from Rinaadi station

Figure 7: Vertical and horizontal motions of Tabas and Northridge earthquake.

Figure $7, \partial_{\mathrm{PGA}}$ of Tabas and Northridge earthquake are, respectively, 0.81 and 1.01 , both exceeding the value of $2 / 3$. High values of $\partial_{\mathrm{PGA}}$ can be notably modified as the axial load in columns, which may produce undesirable phenomena, for example, buckling of the longitudinal bars, brittle failure in compression, bond deterioration, or failure under tension deterioration in these elements which were observed in Northridge and Kobe earthquake $[54,55]$. The effect of high values of vertical ground motions on seismic response of high-speed railway bridge.

Scaling of ground motion records is a necessary element of nonlinear dynamic analysis [56]. Ground motion scaling procedures use the peak value of input ground accelerations, maintaining the original ground motion history characteristics, including the response spectrum of each recorded ground motion. However, the use of large input numbers of ground motion records is recommended to prevent the response values of structure from undergoing the bias created by the response spectrum characteristics of any one ground motion. The relatively large factor is required to compensate insufficient energy for the structure as it is sure to obtain ground motion with sufficient input energy [57] when this is applied to nonlinear seismic response analyses. All records are scaled to match a particular level of ground motions. According to the provisions of seismic codes [58,59], the particular level of ground motions is the high-level earthquake (design horizontal acceleration $a=0.4 \mathrm{~g}$ ), which is equivalent to the Maximum Credible Level Earthquake of FEMA-356 [60]. FEA-356 specified the following three hazard levels:

(i) hazard level 1 (service level earthquake) - a relatively frequent earthquake with a $50 \%$ probability of being exceed in 50 years;

(ii) hazard level II (design level earthquake)—earthquake at this level of hazard are normally assumed to have a $10 \%$ probability of being exceed in 50 years;

(iii) hazard level III (a maximum credible level earthquake) - the maximum credible event at the site with a $2 \%$ probability of being exceed in 50 years.

It should be mentioned that the vertical records use the same scale factors (SF) from their corresponding horizontal components, and the SF of ground motions are listed in the Tables 4 and 5 corresponding to the selected seismic hazard.

\section{Case Study}

5.1. Basic Parameters of Vehicle-Bridge System. A case study bridge model is used to explore the forward directivity on the seismic response of the bridge. The adapted case study is a typical multispan simply supported boxing bridge under high-speed trains. This bridge type represents more than $90 \%$ 


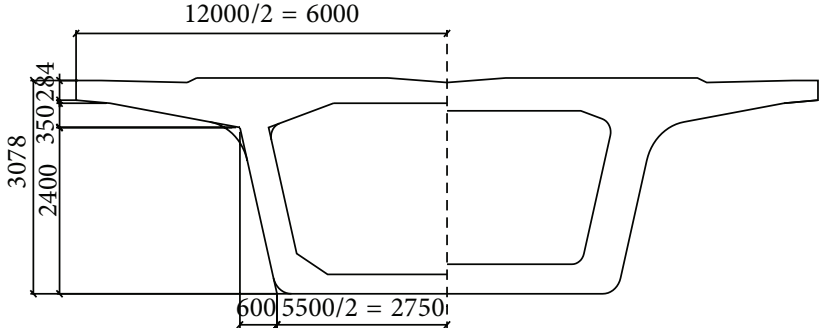

(a) Bridge deck (unit: $\mathrm{mm}$ )

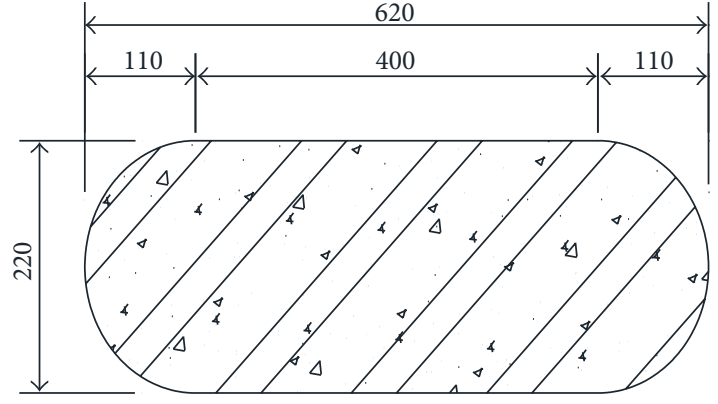

(b) Bridge pier (unit: $\mathrm{cm}$ )

FIGURE 8: Cross-section of bridge deck and pier.

TABLE 6: Geometric constants of model boxinging girders.

\begin{tabular}{lcccccc}
\hline $\begin{array}{l}\text { Length of } \\
\text { girder } /(\mathrm{m})\end{array}$ & $\begin{array}{c}\text { Height of } \\
\text { girder } /(\mathrm{m})\end{array}$ & $\begin{array}{c}\text { Deck } \\
\text { width } /(\mathrm{m})\end{array}$ & $\begin{array}{c}\text { Area of } \\
\text { girder } /\left(\mathrm{m}^{2}\right)\end{array}$ & $\begin{array}{c}I_{y y} \text { of } \\
\text { girder } /\left(\mathrm{m}^{4}\right)\end{array}$ & $\begin{array}{c}I_{z z} \text { of } \\
\text { girder } /\left(\mathrm{m}^{4}\right)\end{array}$ & $\begin{array}{c}\text { Linear mass } \\
\text { of } \\
\text { girder } /(\mathrm{kg} / \mathrm{m})\end{array}$ \\
\hline 32 & 3.05 & 12 & 8.6597 & 10.811 & 80.945 \\
\hline
\end{tabular}

of China's high-speed railway bridge in including BeijingTianjin line and Beijing-Shanghai line [61]. The bridges are located in designs that comply with the Temporary Provisions of Newly-Built 300-350 km/h Passenger Special Railway Bridge Design [62]. The cross-sectional dimensions of the boxing girder and bridge piers of a chosen five-span simply supported bridge for this study can be seen in Figure 8 . The related parameters are listed below. The bridge consists of five $32 \mathrm{~m}$ spans of PC box girders, the piers are 10-20 m high, with round-end sections and pile foundations. Mounted on the piers are fixed pot neoprene bearings. All the piers are cast in situation and concrete strength grade is C35 (the Young's modulus is $3.15 \mathrm{E} 4 \mathrm{~N} / \mathrm{mm}^{2}$ ), longitudinal enforcement ratio of cross-section is $0.43 \%$. Poisson's ratio $v=0.2$. Geometric constants of model boxing girders and round-shaped solid pier are seen in Tables 6 and 7. The secondary dead load (i.e., slab ballastless track structure, $=184 \mathrm{kN} / \mathrm{m}$ ) regarded as the participating vibration mass is spreaded over the boxing girder.

The 3D bridge model was developed, and the elasticplastic analysis of the bridge under high-speed vehicles in this study is conducted based on the second development and a parametric scripting language called APDL of the commercial soft package ANSYS. The model uses a single line of $3 \mathrm{D}$ element for the superstructure and piers; when present, elastomeric bearing are modeled with linear springs element between appropriate substructure and superstructure element. On the modeling of the VTB element, sprung mass (car body and bogie) $M_{v}$ and unsprung mass (wheelset) $m_{w}$ are modeling with mass element, the primary suspension system modeled with linear springs, and CRTS II slab ballastless track are modeling with linear springs element. In each case, pier bases are assumed to be rigidly connected to the pile caps. These caps are assumed to be fully fixed, having no soil or pile deformation effects included. The ground motions are all scaled to suit the high level of earthquake for
TABLE 7: Geometric constants of model round-shaped solid pier.

\begin{tabular}{lcc}
\hline Area of pier $\left(\mathrm{m}^{2}\right)$ & $I_{y y}$ of pier $/\left(\mathrm{m}^{4}\right)$ & $I_{z z}$ of $\operatorname{pier} /\left(\mathrm{m}^{4}\right)$ \\
\hline 11.141 & 3.4515 & 29.351 \\
\hline
\end{tabular}

the bridge structure and then input into the structure in order to compute structural nonlinear seismic response.

5.2. Elastic-Plastic Analysis of Vehicle-Bridge System. The ICE series high-speed trains of Germany are employed as vehicles live load. With more significant $30 \mathrm{~s}$ of registration, the horizontal and vertical ground motion components of the near-fault ground motions considered in the analysis are shown. Take a $14 \mathrm{~m}$ pier height as an example to analyze the natural vibration characteristics of the bridge system by an eigenvalue analysis. The foundational period $(T)$ of vibration corresponding to the five-span high-speed railway bridge is $0.259 \mathrm{~s}$. This amounts to be less than the pulse periods $\left(T_{P}\right)$ of the FD pulse ground motions; that is, the bridge can then be labeled a short period structure $[20,46]$.

Research and experimental results show that the base of the piers will step into the nonlinear stage under highlevel earthquake. The elastic-plastic method is used to analyze the seismic responses under high-level earthquake. Elastic-plastic deformation of pier bottom can be calculated by means of the moment-curvature relationship program UCFYBER [63]. Here the yield moment and yield rotation angle, the ultimate moment and the ultimate rotation angle can be calculated, and then by applying the momentcurvature relationship to the nonlinear beam element in ANSYS software, the elastic-plastic seismic responses of bridge can be calculated. The values of skeleton-frame curves of moment-curvature relationship are seen in Table 8 .

According to cross-sectional dimension of the pier, the locations of reinforced steels, and stress-strain relationship 
TABLE 8: Calculated values of skeleton-frame curves of moment-curvature relationship.

\begin{tabular}{lcccc}
\hline Position & $\begin{array}{c}\text { Yield } \\
\text { curvature } /\left(\mathrm{m}^{-1}\right)\end{array}$ & $\begin{array}{c}\text { Yield } \\
\text { moment } /(\mathrm{kN} \cdot \mathrm{m})\end{array}$ & $\begin{array}{c}\text { Ultimate } \\
\text { curvature } /\left(\mathrm{m}^{-1}\right)\end{array}$ & $\mathrm{moment} /(\mathrm{kN} \cdot \mathrm{m})$ \\
\hline Longitudinal & $0.47 \times 10^{-3}$ & $56.40 \times 10^{3}$ & $17.87 \times 10^{-3}$ & $97.90 \times 10^{3}$ \\
Lateral & $1.45 \times 10^{-3}$ & $24.80 \times 10^{3}$ & $52.63 \times 10^{-3}$ & $35.80 \times 10^{3}$ \\
\hline
\end{tabular}

TABLE 9: Seismic response of high-speed railway bridge with $350 \mathrm{~km} / \mathrm{h}$ vehicle speed and pier height $14 \mathrm{~m}$ under high-level near-fault earthquake action.

\begin{tabular}{|c|c|c|c|c|c|}
\hline Earthquake & $\begin{array}{c}\text { Transverse } \\
\text { displacement at } \\
\text { midspan/(mm) }\end{array}$ & $\begin{array}{c}\text { Vertical } \\
\text { displacement at } \\
\text { midspan } /(\mathrm{mm})\end{array}$ & $\begin{array}{l}\text { Transverse } \\
\text { displacement at } \\
\text { the top of the } \\
\text { piers } /(\mathrm{mm})\end{array}$ & $\begin{array}{l}\text { Transverse shear } \\
\text { force at the base } \\
\text { of pier }\left(\times 10^{3} \mathrm{kN}\right)\end{array}$ & $\begin{array}{c}\text { Bending } \\
\text { moment at the } \\
\text { base of pier } \\
\left(\times 10^{3} \mathrm{kN} \cdot \mathrm{m}\right)\end{array}$ \\
\hline Iran Tabas-Tabas & 68.03 & 24.41 & 69.31 & 6.838 & 80.768 \\
\hline $\begin{array}{l}\text { Loma Prieta-Los } \\
\text { Gatos-Lexington Dam }\end{array}$ & 67.53 & 7.15 & 75.20 & 7.814 & 79.820 \\
\hline Turkey Kocaeli-Yarimca & 89.31 & 43.61 & 110.80 & 8.240 & 88.402 \\
\hline $\begin{array}{l}\text { Northridge-Newhall-Fire } \\
\text { Station }\end{array}$ & 105.30 & 27.53 & 125.70 & 8.127 & 85.412 \\
\hline Northridge-Rinaadi & 56.70 & 13.48 & 91.63 & 6.299 & 75.226 \\
\hline Sanfernando-Pacoima Dam & 53.77 & 13.67 & 58.47 & 6.509 & 70.425 \\
\hline
\end{tabular}

TABLE 10: Seismic response of high-speed railway bridge with $350 \mathrm{~km} / \mathrm{h}$ vehicle speed and pier height $14 \mathrm{~m}$ under high-level far-fault earthquake action.

\begin{tabular}{|c|c|c|c|c|c|}
\hline Earthquake & $\begin{array}{c}\text { Transverse } \\
\text { displacement at } \\
\text { midspan } /(\mathrm{mm})\end{array}$ & $\begin{array}{c}\text { Vertical } \\
\text { displacement at } \\
\text { midspan/(mm) }\end{array}$ & $\begin{array}{c}\text { Transverse } \\
\text { displacement at the } \\
\text { top of the } \\
\text { piers } /(\mathrm{mm})\end{array}$ & $\begin{array}{l}\text { Transverse shear } \\
\text { force at the base of } \\
\quad \text { pier }\left(\times 10^{3} \mathrm{kN}\right)\end{array}$ & $\begin{array}{l}\text { Bending moment } \\
\text { at the base of pier } \\
\qquad\left(\times 10^{3} \mathrm{kN} \cdot \mathrm{m}\right)\end{array}$ \\
\hline Iran Tabas-Ferdows & 52.33 & 14.57 & 59.70 & 6.280 & 69.167 \\
\hline Loma Prieta-Cliff House & 56.02 & 5.26 & 55.41 & 6.416 & 70.129 \\
\hline Turkey Kocaeli-Ambarli & 94.10 & 1.51 & 89.92 & 9.081 & 90.3735 \\
\hline $\begin{array}{l}\text { Northridge-Century City CC } \\
\text { North }\end{array}$ & 104.20 & 13.06 & 84.99 & 8.455 & 70.198 \\
\hline Loma Prieta-Presidio & 44.39 & 14.56 & 44.65 & 4.907 & 63.305 \\
\hline $\begin{array}{l}\text { Imperial Valley-Calexico Fire } \\
\text { Station }\end{array}$ & 128.40 & 27.94 & 102.90 & 6.780 & 85.034 \\
\hline
\end{tabular}

of confined concrete [64], the key values of skeleton-frame curves of moment-curvature relationship can be calculated, and those values can be substitute into the nonlinear beam element in ANSYS software. After the yield moment and curvature and the ultimate moment and curvature are calculated, the plastic hinge position at the base of the pier can be determined.

The moment-rotation angle relationship curve is plotted according to the former analysis method. Take the $14 \mathrm{~m}$ pier height, for example, the vehicle marshalling pass over bridge at the speed of $350 \mathrm{~km} / \mathrm{h}$; lateral and vertical highlevel earthquake are considered, respectively. Tables 9 and 10 show the seismic response of high-speed railway bridge with $350 \mathrm{~km} / \mathrm{h}$ vehicle speed and pier height $14 \mathrm{~m}$ under highlevel near-fault/far-fault earthquake action. It is clear that the displacement at mid-span of the girder and the pier top, moment of the pier bottom tend to increase under near-fault ground motions compared with those under the far-fault ground motions. When the bases of piers develop the plastic hinge under high-level earthquake, the seismic response of the bridge is different under different earthquake wave. The elastic-plastic deformation of the pier base is different. It can be inferred from Table 9 that the magnitude of the input energy by itself is not a complete measure of the severity of the ground motion. For example, the peak seismic responses of the bridge can be caused by ground motions with smaller input energies.

Table 10 demonstrates the seismic response of the Calexico Fire Station record of Imperial Valley 1979 earthquake and Century City CC North record of Northridge 1994 earthquake. The response is much more severe than what other earthquake records show. According to the research of Kalkan and Kunnath [53], the seismic demands are clearly amplified as the pulse period $\left(T_{P}\right)$ as it approaches the fundamental 


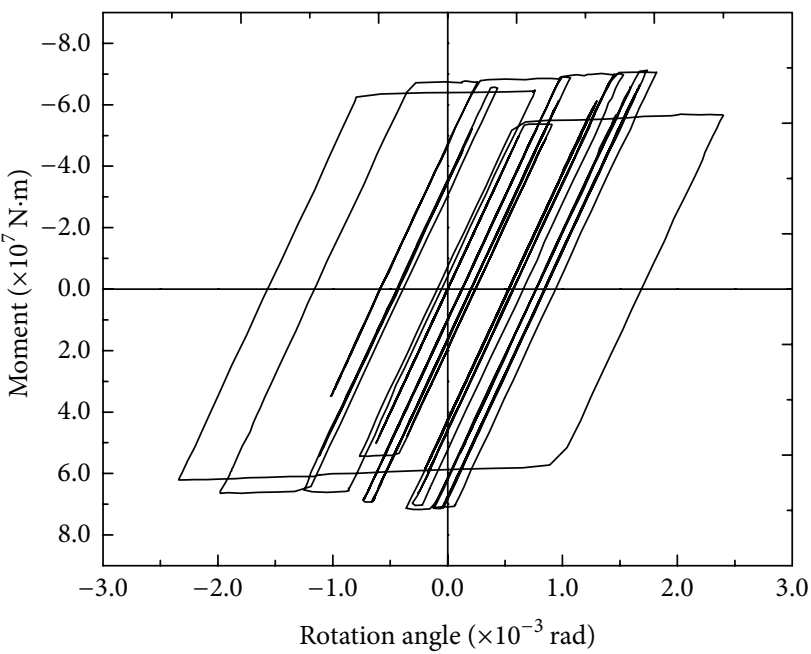

(a) First element at the base of pier

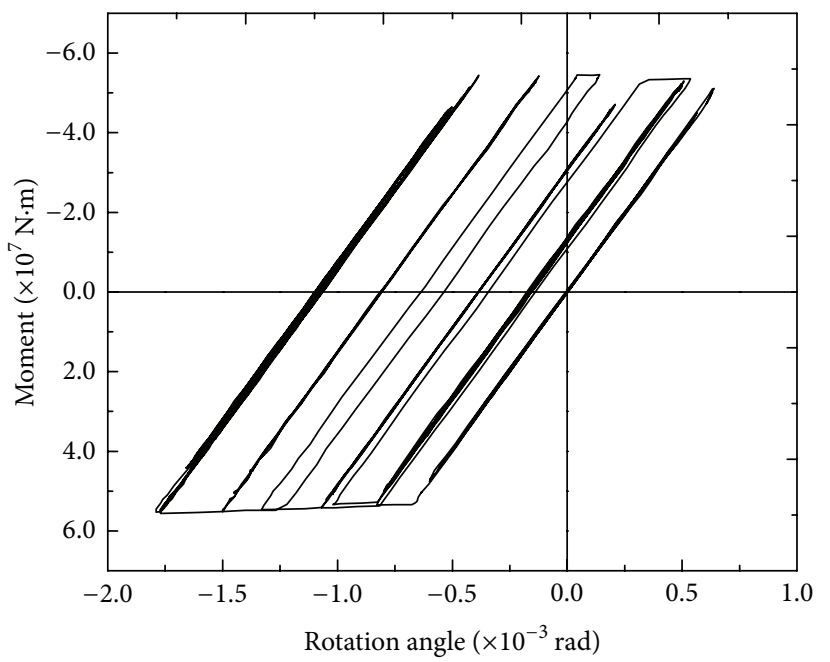

(c) Third element at the base of pier

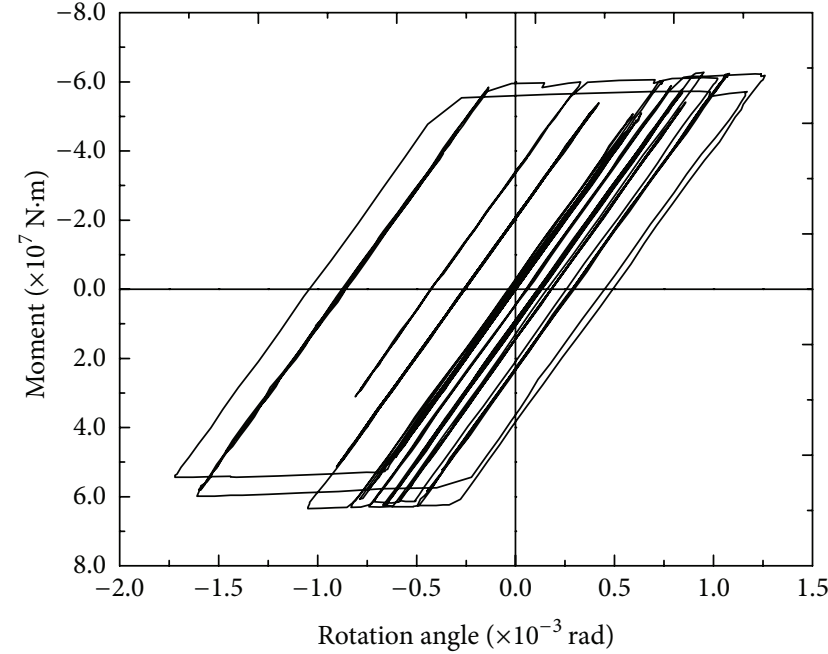

(b) Second element at the base of pier

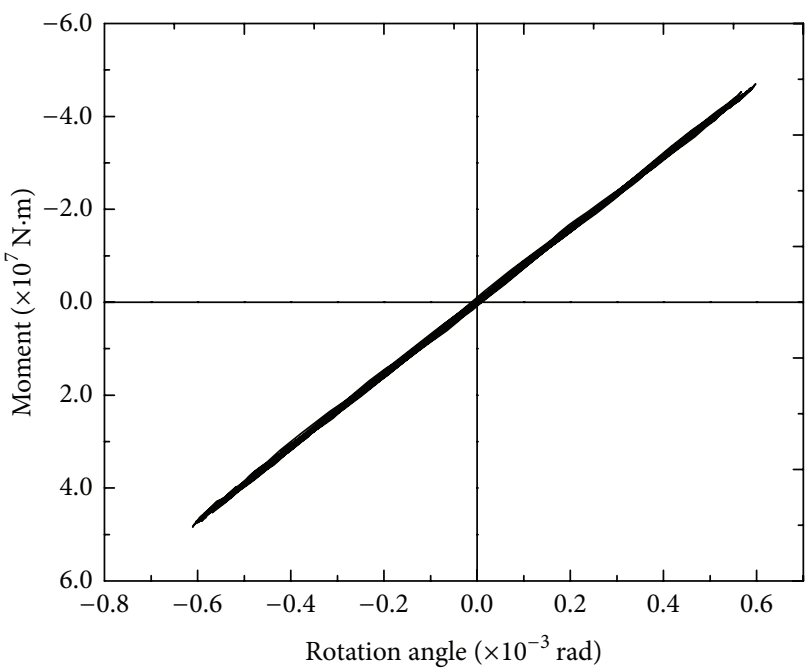

(d) Fourth element at the base of pier

FIGURE 9: Moment-rotation relationship at the element of pier bottom for near-fault ground motion record of Tabas-TR with $350 \mathrm{~km} / \mathrm{h}$ vehicle speed and $14 \mathrm{~m}$ pier.

period $(T)$ of the structure. But the literature did not include a detailed seismic response of the Calexico Fire Station record of Imperial Valley 1979 earthquake and a detailed seismic response of the Century City CC North record of Northridge 1994 earthquake. The two records are listed in the far-fault ground motions database, and as can be seen in Table 10, the seismic response of the Calexico Fire Station record of the Imperial Valley 1979 earthquake and Century City CC North record of the Northridge 1994 earthquake shows more characteristics of near-fault earthquake, while also showing the greater acceleration and velocity spectra values at the little frequency. At the same time, the rupture distance is $10.45 \mathrm{~km}$ and $23.41 \mathrm{~km}$. On the source-to-site distance, according to the site-source provision in FEMA P695 [65], the source-to-site distance boundary between near-field and far-field records is arbitrary, but generally consistent with the "near fault" region of Maximum Considered Earthquake design values maps in ASCE/SEI 7-05 [66]. Several different measures of this distance are available. For the project (FEMA P695), the source-to-site distance was taken as the average of Campbell and Joyner-Boore fault distances provided in the PEER NGA database. Although the source-to-site distance of the two records is a little more than $10 \mathrm{~km}$, it suggested that they should be listed in near-fault earthquake database in the future research.

Figure 9 illustrates the moment-rotation relationship at the base element of pier for the Tabas record of Tabas 1978 earthquake with $350 \mathrm{~km} / \mathrm{h}$ vehicle speed and $14 \mathrm{~m}$ pier. Reference [53] demonstrated that the largest deformation demands in near-fault shaking are associated with fewer reversed cycles of loading. Figure 9 allows for the inference that with hysteretic characteristics of the near-fault directivity of pulse-like earthquakes, the more just expression should be the moment-rotation relationship of a pier base is 


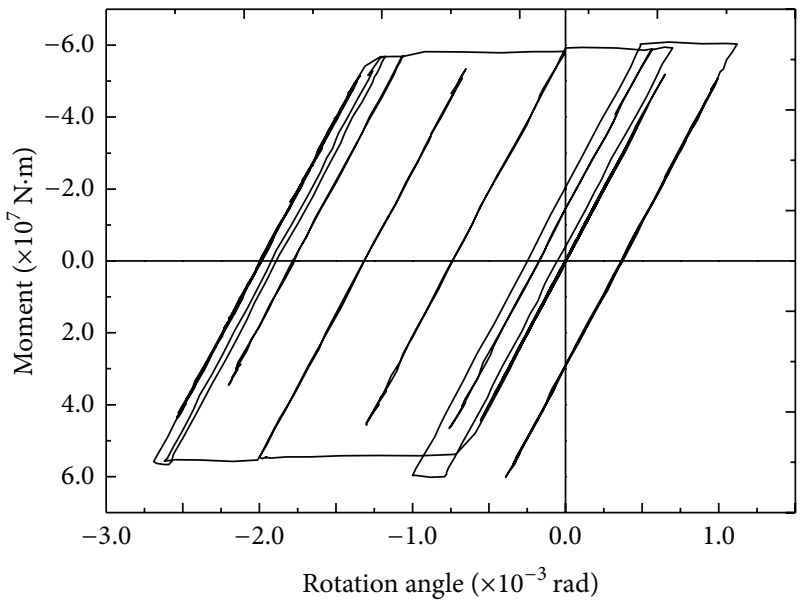

(a) First element at the base of pier

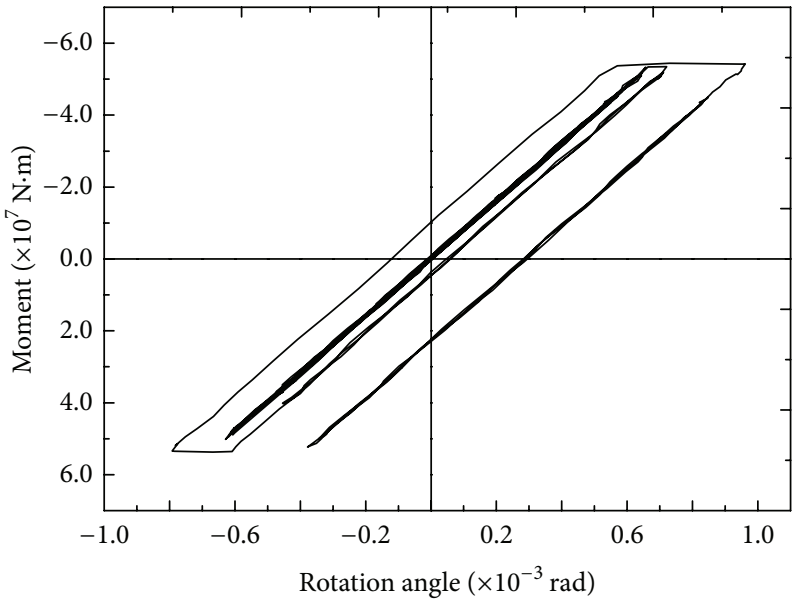

(b) Second element at the base of pier

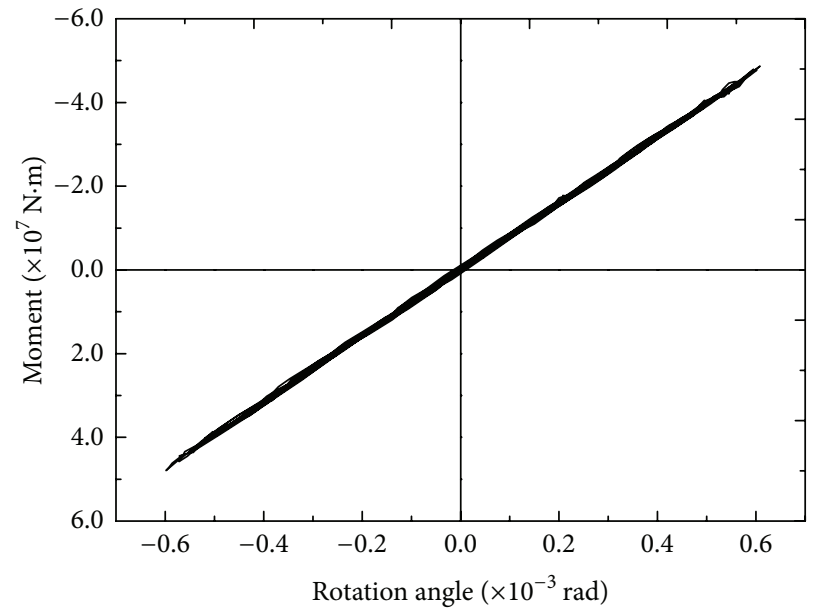

(c) Third element at the base of pier

FIGURE 10: Moment-rotation relationship at the element of pier bottom for far-fault ground motion record of Tabas-FER-T1 with $350 \mathrm{~km} / \mathrm{h}$ vehicle speed and $14 \mathrm{~m}$ pier.

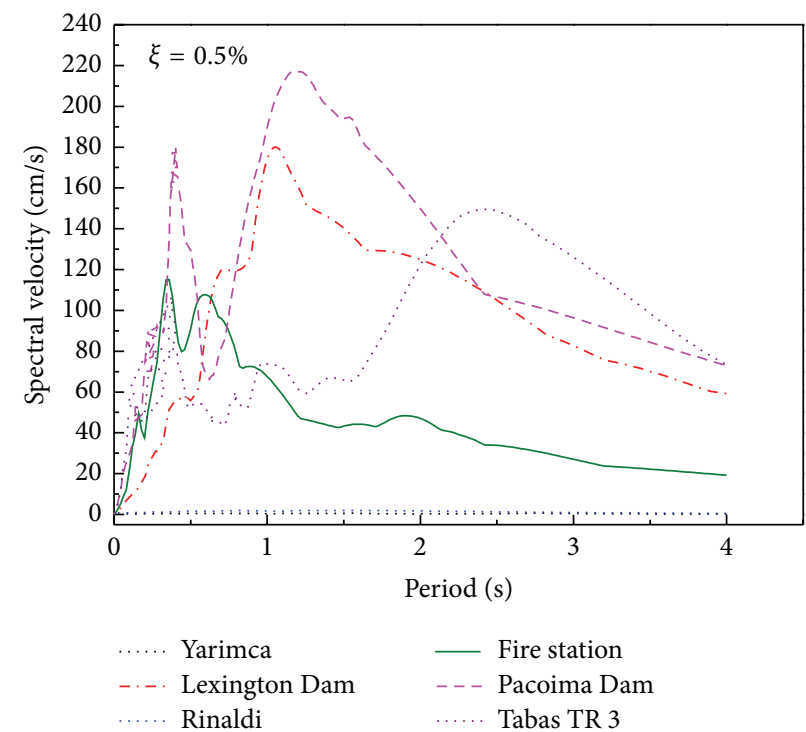

FIGURE 11: Velocity spectra of near-fault ground motions. 


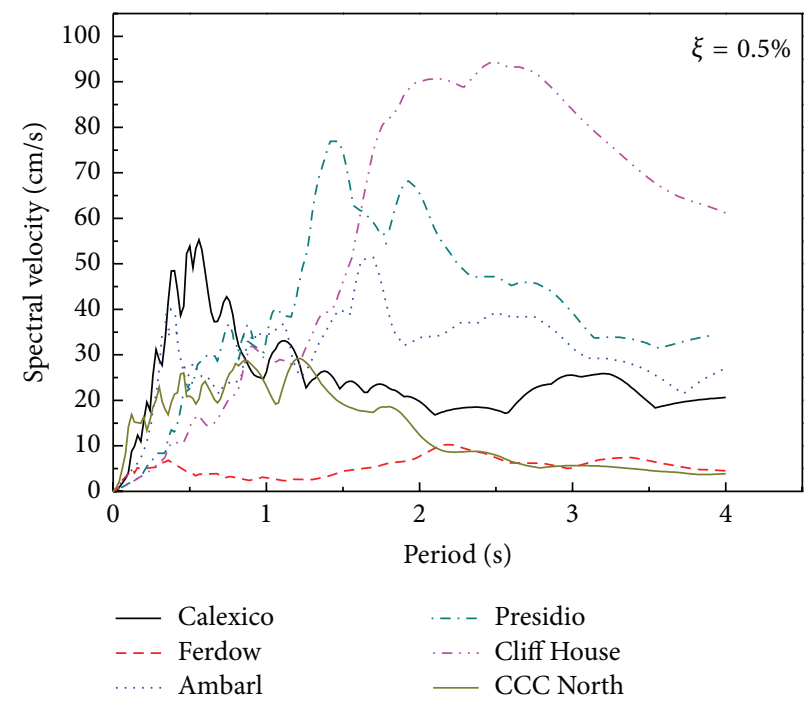

FIGURE 12: Velocity spectra of far-fault ground motions.

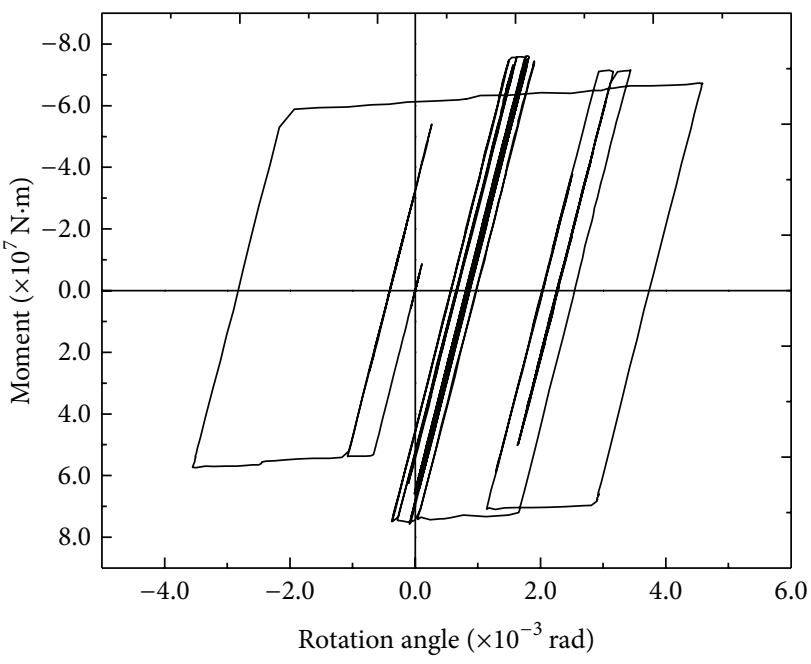

(a) First element at the base of pier

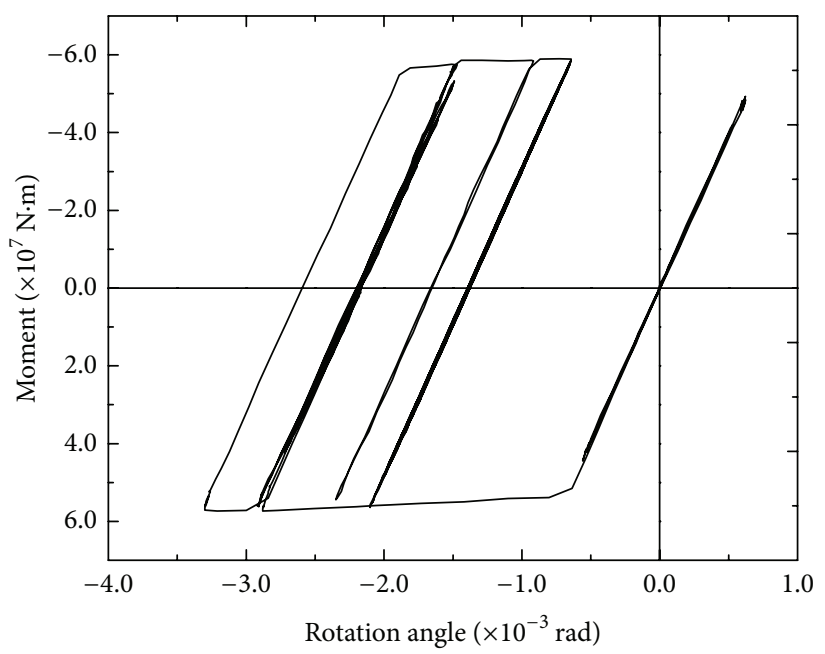

(c) Third element at the base of pier

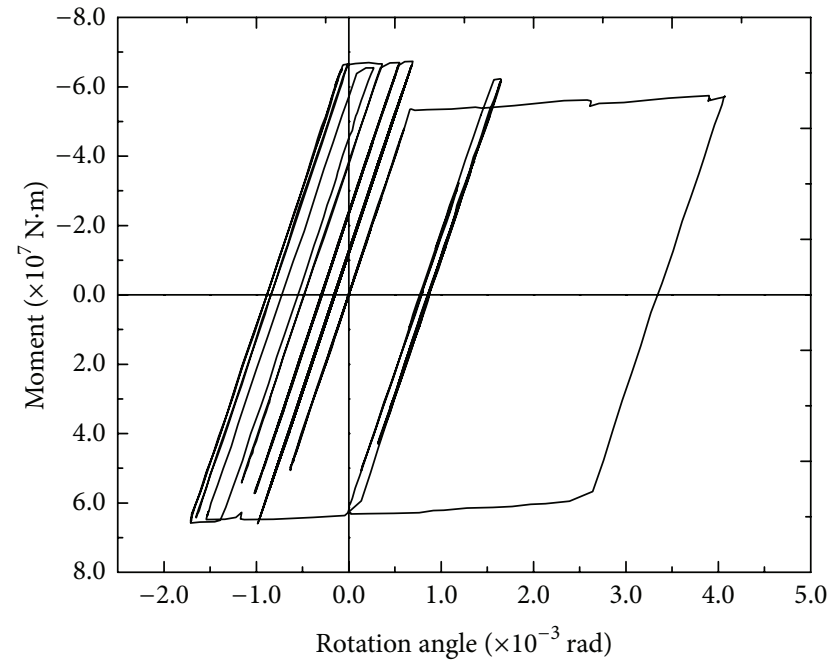

(b) Second element at the base of pier

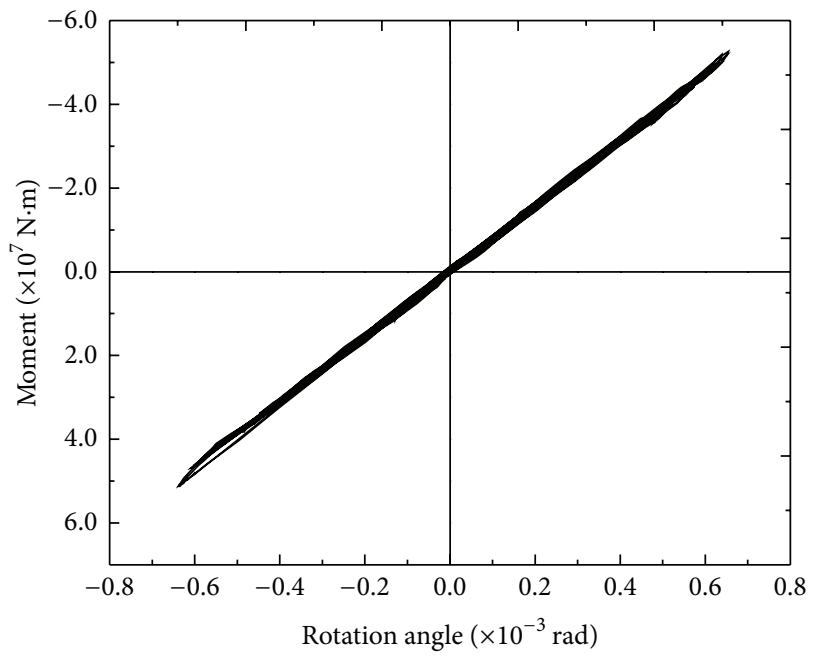

(d) Fourth element at the base of pier

FIGURE 13: Moment-rotation relationship at the element of pier bottom for lateral near-fault ground motion record of Northridge-Newhall, LA County Fire Station with $350 \mathrm{~km} / \mathrm{h}$ vehicle speed and $14 \mathrm{~m}$ pier. 


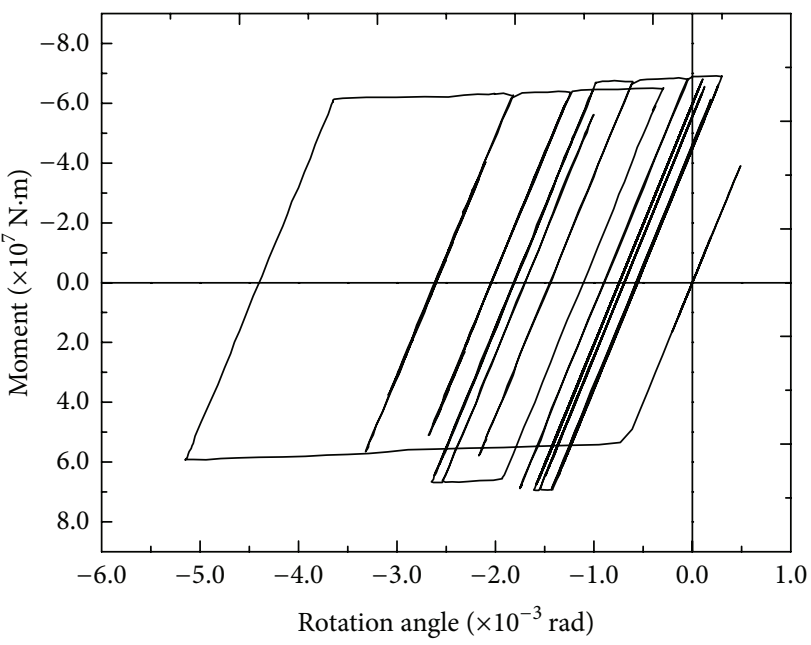

(a) First element at the base of pier

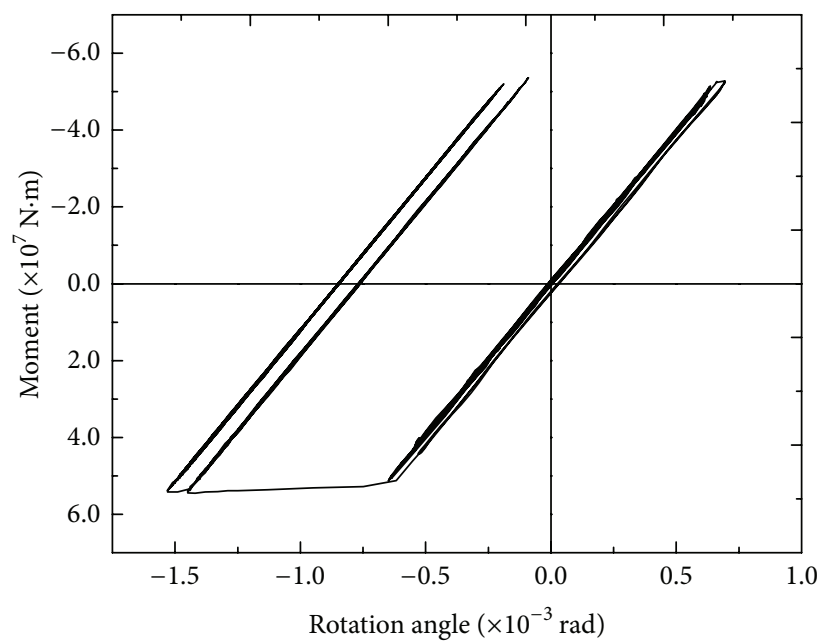

(c) Third element at the base of pier

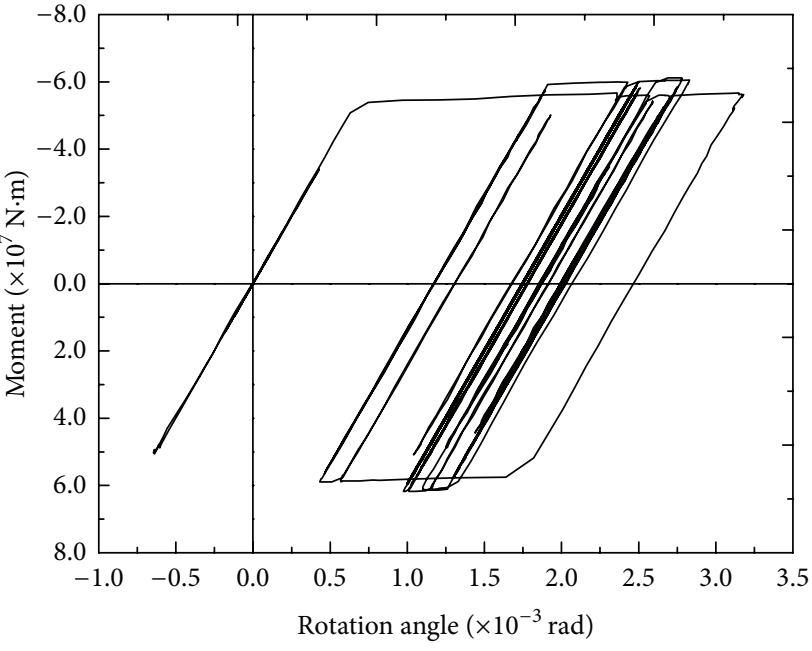

(b) Second element at the base of pier

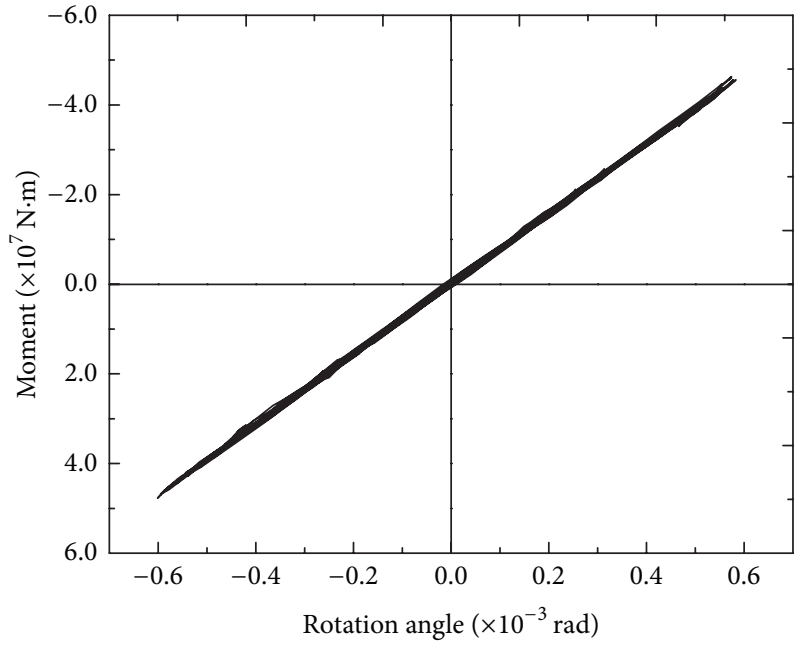

(d) Fourth element at the base of pier

FIGURE 14: Moment-rotation relationship at the element of pier bottom for lateral near-fault ground motion record of Northridge-Rinaadi station with $350 \mathrm{~km} / \mathrm{h}$ vehicle speed and $14 \mathrm{~m}$ pier.

characterized by the central strengthened hysteretic cycles. At some point of the loading time-history curve corresponding to the time of the pulse, this is due to the dissipation of sudden energy in a short period of time in a single or few excursions. It requires the bridge piers to dissipate considerable input energy in a single or relatively few plastic cycles, meaning that the ductility capacity of the piers should be improved.

On the other hand, as can be shown in Figure 10 which illustrates the moment-rotation relationship at the base element of pier for the Ferdows record of the Tabas 1978 earthquake with $350 \mathrm{~km} / \mathrm{h}$ vehicle speed and $14 \mathrm{~m}$ pier, the energy dissipation on the bridge system subjected to a far-fault motion tends to gradually increase over a longer duration, causing an incremental build-up of input energy. As is shown in Figure 9, followed by several cycles of elastic action, the consequence of a single predominant peak is a well-pronounced permanent offset displacement, and the subsequent response is essentially a series of elastic cycles about this deformed configuration.

To put the severity of near-fault ground motions in perspective with the severity of ground motions represented by current codes, the velocity spectra of near-fault ground motions are presented in the study with given a damping ratio of $\xi=5 \%$. Although some of the records have more than one clear velocity peak, an important observation from the near-fault spectra (Figures 11 and 12) is the existence of a predominant peak in the velocity spectrum of most of the near-fault records. The predominant peak of the velocity spectrum is used to later estimate the period of the pulse contained in the near-fault record.

Figure 11 illustrates the velocity spectra of 6 recorded near-fault time histories. This figure is presented for two reasons: to illustrate the great variability in near-fault response spectra and second and to put the severity of near-fault 
ground motions in perspective with the severity of ground motions represented by current codes. The velocity spectra of a reference set of 6 far-fault ground motions records are presented in Figure 12. The velocity spectra value of near-fault ground motions is greater when the period of far-fault ground motions is within $3 \mathrm{sec}$, and the velocity spectra value is greater when the period exceeds $3 \mathrm{sec}$. This is significant to railway simply supported bridges which have short foundational periods.

Vertical ground motion component is not considered explicitly in the design of ordinary bridges. A comparison analysis of vertical ground motion effects is presented in the study to evaluate the vertical ground motion effects on the response of the high-speed railway bridges. Plastic hinges owing to the vertical acceleration are expected at the pier bottom where an amplification of the vertical motion is also expected to depend on the high value of the vertical acceleration, and the spacing of the hysteresis hoops is large and can be manifested in the moment-rotation relationship at the element of pier bottom for lateral near-fault ground motion record of the Northridge-Newhall, LA County Fire Station, and Northridge-Rinaadi station in Figures 13 and 14.

Since Newmark et al. [67] suggested that the average peak vertical-to-horizontal spectral ratio $\partial_{\mathrm{PGA}}$ can reasonably be taken as $2 / 3$, almost all modem codes accept the value and use it to scale down the horizontal spectrum and consequently arrive at a vertical spectrum. This implies that the verticalto-horizontal PGA ratio $\partial_{\mathrm{PGA}}$ is also $2 / 3$ assuming constant amplification. Whereas the latter study is based on a rather limited dataset of 33 components and uses it so as to scale down the horizontal spectrum in order to arrive at a vertical spectrum. However, there is strong evidence that the $\partial_{\mathrm{PGA}}$ value of the $\mathrm{V} / \mathrm{H}$ ratio is unconservative in the near-fault ground motion [68]. According to the site natural period, rupture distance, and the site properties, the $\partial_{\mathrm{PGA}}$ value should be revised in the future research, while the discreteness of $\partial_{\mathrm{PGA}}$ should also be considered.

\section{Summary}

The study summarized in this paper addresses the nonlinear seismic response characteristics of high-speed railway bridge structures that are subjected to near-fault FD pulse-like ground motions. A procedure for estimating the effects of FD pulse on the seismic response of high-speed railway bridge is introduced based on the PEER NAG strong ground motion database. The VTB element is presented to simulate the interaction between a train and a bridge. A train is modeled as a series of sprung masses concentrated at the axle positions, while the effects of the high values of the vertical accelerations are taken into consideration. It is emphasized that the conclusions and results presented in this paper are applicable only within the context of the assumptions made. The conclusions of this study are summarized for the short period railway bridge $\left(T \leq T_{P}\right)$, as subjected to near-fault FD pulse-like ground motions as follows.
(1) The directivity pulse effect tends to increase the displacement response of the girder and pier top, moment response of the pier bottom in inelastic high-speed railway bridge relative to far-fault ground motion or nonpulse-like motions. These displacement demands may increase structural and nonstructural damage.

(2) The largest deformation demands in near-fault directivity pulse-like ground motions shaking are associated with fewer reversed cycles of loading. In regard to the hysteretic characteristics of the near-fault directivity pulse-like earthquake, the expression used should be the moment-rotation relationship of pier bottom is characterized by the central strengthened hysteretic cycles at some point of the loading timehistory, which may be corresponding to the time of the pulse. It requires that the bridge piers to dissipate considerable input energy in a single or relatively few plastic cycles. This means that the ductility capacity of the piers should be improved.

(3) As the high values of the acceleration ratio $\partial_{\mathrm{PGA}}$ are involved in near-fault ground motions, there are the large vertical deflections in the midspan of girder; therefore, high values of $\partial_{\mathrm{PGA}}$ can notably modify the axial load in the bridge piers. This can influence the hysteretic behavior; for example, the spacing of the hysteresis hoops is large; the constant amplification $\partial_{\mathrm{PGA}}$ is taken as $2 / 3$ by most of codes is unconservative in the near-fault ground motion. According to the site natural period, rupture distance, and the site properties, the $\partial_{\mathrm{PGA}}$ value should be revised, and the discreteness of the $\partial_{\mathrm{PGA}}$ should be considered.

\section{Conflict of Interests}

The authors declare that there is no conflict of interests regarding the publication of this paper.

\section{Acknowledgments}

The research summarized in this paper was supported by the Major State Basic Research Development Program of China ("973" Program) through Grant no. 2013CB036203, China Postdoctoral Science Foundation through Grant no. 2013M530022, Science and Technology Plan Projects of Ministry of Housing and Urban-Rural Development of the People's Republic of China through Grant no. 2013-K5-31, High-Level Scientific Research Foundation for the introduction of talent of Yangzhou University, the Open Fund of the National Engineering Laboratory for High Speed Railway Construction, the Program for Changjiang Scholars and Innovative Research Team in University "PCSIRT" Project through Grant no. IRT1296), and National Natural Science Foundation of China through Grant no. 50908236. This support is gratefully acknowledged. 


\section{References}

[1] P. G. Somerville, N. F. Smith, R. W. Graves, and N. A. Abrahamson, "Modification of empirical strong ground motion attenuation relations to include the amplitude and duration effects of rupture directivity," Seismological Research Letters, vol. 68, no. 1, pp. 199-222, 1997.

[2] H. Benioff, "Mechanism and strain characteristics of the White Wolf fault as indicated by the aftershock sequence," in Earthquakes in Kern County, California during 1952, Author's Separate, Part II Seismology, Bulletin 171, pp. 199-200, California Department of Natural Resources, Division of Mines, 1955.

[3] K. Kasahara, "An attempt to detect azimuth effect on spectral structures of seismicwaves: the Alaskan earthquakes of April 7, 1958," Bulletin of the Earthquake Research Institute, vol. 38, no. 2, pp. 207-218, 1960.

[4] N. A. Haskell, "Total energy and energy spectral density of elastic wave radiation from propagating faults," Bulletin of the Seismological Society of America A, vol. 54, no. 6, pp. 1811-1842, 1964.

[5] A. Ben-Menahem, "Radiation of seismic surface-waves from finite moving sources," Bulletin of the Seismological Society of America, vol. 51, no. 3, pp. 401-435, 1961.

[6] T. H. Heaton, "The 1971 San Fernando earthquake; a double event?" Bulletin of the Seismological Society of America A, vol. 72, no. 6, pp. 2037-2062, 1982.

[7] D. M. Boore and R. L. Porcella, "Peak horizontal ground motions from the 1979 Imperial valley earthquake: comparison with data from previous earthquakes," in Selected Papers on the Imperial Valley, California, Earthquake of October 15, 1979, R. Christopher, Ed., U.S. Geological Survey, Open-File Report, United States Department of the Interior, Geological Survey, Menlo Park, Calif, USA, 1980.

[8] D. J. Wald, T. H. Heaton, and K. W. Hudnut, "The slip history of the 1994 Northridge, California, earthquake determined from strong-motion, teleseismic, GPS, and leveling data," Bulletin of the Seismological Society of America B, vol. 86, no. 1, pp. S49S70, 1996

[9] Y.-G. Li, K. Aki, J. E. Vidale, and M. G. Alvarez, "A delineation of the Nojima fault ruptured in the M7.2 Kobe, Japan, earthquake of 1995 using fault zone trapped waves," Journal of Geophysical Research B, vol. 103, no. 4, pp. 7247-7263, 1998.

[10] W.-C. Chi, D. Dreger, and A. Kaverina, "Finite-source modeling of the 1999 Taiwan (Chi-Chi) earthquake derived from a dense strong-motion network," Bulletin of the Seismological Society of America, vol. 91, no. 5, pp. 1144-1157, 2001.

[11] S. W. Park, H. Ghasemi, J. Shen, P. G. Somerville, W. P. Yen, and M. Yashinsky, "Simulation of the seismic performance of the Bolu Viaduct subjected to near-fault ground motions," Earthquake Engineering \& Structural Dynamics, vol. 33, no. 13, pp. 1249-1270, 2004.

[12] B. Alavi and H. Krawinkler, "Consideration of near-fault ground motion effects in seismic design," in Proceedings of the 12th World Conference on Earthquake Engineering, Paper no. 2665, 2000.

[13] H. Choi, M. Saiidi, P. G. Somerville, and S. S. El-Azazy, "Bridge seismic analysis procedure to address near-fault effects," in Proceedings Caltrans Bridge Research Conference, California Transportation Foundation and California Department of Transportation, Sacramento, Calif, USA, 2005.

[14] A. Mortezaei and H. R. Ronagh, "Plastic hinge length of reinforced concrete columns subjected to both far-fault and near-fault ground motions having forward directivity," The Structural Design of Tall and Special Buildings, vol. 22, no. 12, pp. 903-926, 2013.

[15] G. A. MacRae, D. V. Morrow, and C. W. Roeder, "Nearfault ground motion effects on simple structures," Journal of Structural Engineering, vol. 127, no. 9, pp. 996-1004, 2001.

[16] P. Tothong and C. A. Cornell, "Structural performance assessment under near-source pulse-like ground motions using advanced ground motion intensity measures," Earthquake Engineering \& Structural Dynamics, vol. 37, no. 7, pp. 1013-1037, 2008.

[17] J. W. Baker and C. A. Cornell, "Vector-valued intensity measures for pulse-like near-fault ground motions," Engineering Structures, vol. 30, no. 4, pp. 1048-1057, 2008.

[18] L. Xu, A. Rodriguez-Marek, and L. Xie, "Design spectra including effect of rupture directivity in near-fault region," Earthquake Engineering and Engineering Vibration, vol. 5, no. 2, pp. 159-170, 2006.

[19] E. Chioccarelli and I. Iervolino, "Near-source seismic demand and pulse-like records: a discussion for L'Aquila earthquake," Earthquake Engineering \& Structural Dynamics, vol. 39, no. 9, pp. 1039-1062, 2010.

[20] F. Mazza and A. Vulcano, "Nonlinear dynamic response of r.c. framed structures subjected to near-fault ground motions," Bulletin of Earthquake Engineering, vol. 8, no. 6, pp. 1331-1350, 2010.

[21] L.-K. Chen, L.-Z. Jiang, L.-P. Wang, and B.-F. Luo, "Analysis of elastoplastic seismic response of high-speed railway bridge with round-ended piers," Journal of South China University of Technology, vol. 39, no. 6, pp. 126-131, 2011 (Chinese).

[22] L.-K. Chen, L.-Z. Jiang, Z.-W. Yu, and Z.-P. Zeng, "Study on earthquake characteristics of high-speed railway simplysupported girder bridge," Journal of Vibration and Shock, vol. 30, no. 12, pp. 216-222, 2011 (Chinese).

[23] L. K. Chen, L. Z. Jiang, and Z. Zeng, "Numerical analysis of seismic responses of high-speed railway bridge round-ended piers," Journal of Hunan University Natural Sciences, vol. 39, no. 4, pp. 19-25, 2012 (Chinese).

[24] L. K. Chen, L. Z. Jiang, Z. P. Zeng, and W. G. Long, "Numerical modeling and simulation on seismic performance of highspeed railway bridge system," Noise and Vibration Worldwide, vol. 42, no. 10, pp. 15-22, 2011.

[25] B. Alavi and H. Krawinkler, "Behavior of moment-resisting frame structures subjected to near-fault ground motions," Earthquake Engineering \& Structural Dynamics, vol. 33, no. 6, pp. 687-706, 2004.

[26] W.-I. Liao, C.-H. Loh, and B.-H. Lee, "Comparison of dynamic response of isolated and non-isolated continuous girder bridges subjected to near-fault ground motions," Engineering Structures, vol. 26, no. 14, pp. 2173-2183, 2004.

[27] W.-I. Liao, C.-H. Loh, S. Wan, W.-Y. Jean, and J.-F. Chai, "Dynamic responses of bridges subjected to near-fault ground motions," Journal of Chinese Institute of Engineering, vol. 23, no. 4, pp. 455-464, 2000.

[28] Z. Gulerce, E. Erduran, S. K. Kunnath, and N. A. Abrahamson, "Seismic demand models for probabilistic risk analysis of near fault vertical ground motion effects on ordinary highway bridges," Earthquake Engineering \& Structural Dynamics, vol. 41, no. 2, pp. 159-175, 2012.

[29] Y. Z. Ju, G. P. Yan, and L. Liu, "Experimental study on seismic behaviors of large-scale RC round-ended piers with low reinforcement ratio," China Civil Engineering Journal, vol. 36, no. 11, pp. 66-69, 2003 (Chinese). 
[30] J. Shen, M.-H. Tsai, K.-C. Chang, and G. C. Lee, "Performance of a seismically isolated bridge under near-fault earthquake ground motions," ASCE Journal of Structural Engineering, vol. 130, no. 6, pp. 861-868, 2004.

[31] G. L. Dai, W. S. Liu, and L. Y. Li, "Study of the live load for smalland medium-span bridges of high-speed railways," China Civil Engineering Journal, vol. 45, no. 10, pp. 161-168, 2012 (Chinese).

[32] N. Zhang and H. Xia, "Dynamic analysis of coupled vehiclebridge system based on inter-system iteration method," Computers \& Structures, vol. 114-115, pp. 26-34, 2013.

[33] M. M. Gao and J. Y. Pan, "Coupling vibration analysis for train-track-bridge system," in Proceedings of the 6th European Conference on Structural Dynamics (EURODYN '05), Paris, France, 2005.

[34] X. Z. Li, W. B. Ma, and S. Z. Qiang, "Coupling vibration analysis of vehicle-bridge system by iterative solution method," Journal of Vibration and Shock, vol. 21, no. 3, pp. 21-25, 2002 (Chinese).

[35] J.-S. Jo, H.-J. Jung, and H. Kim, "Finite element analysis of vehicle-bridge interaction by an iterative method," Structural Engineering \& Mechanics, vol. 30, no. 2, pp. 165-176, 2008.

[36] Y. B. Yang and Y. S. Wu, "A versatile element for analyzing vehicle-bridge interaction response," Engineering Structures, vol. 23, no. 5, pp. 452-469, 2001.

[37] Y. K. Cheung, F. T. K. Au, D. Y. Zheng, and Y. S. Cheng, "Vibration of multispan non-uniform bridges under moving vehicles and trains by using modified beam vibration functions," Journal of Sound and Vibration, vol. 228, no. 3, pp. 611-628, 1999.

[38] H. Xia, Y. Han, N. Zhang, and W. W. Guo, "Dynamic analysis of train-bridge system subjected to non-uniform seismic excitations," Earthquake Engineering \& Structural Dynamics, vol. 35, no. 12, pp. 1563-1579, 2006.

[39] J. C. O. Nielsen and T. J. S. Abrahamsson, "Coupling of physical and modal components for analysis of moving non-linear dynamic systems on general beam structures," International Journal for Numerical Methods in Engineering, vol. 33, no. 9, pp. 1843-1859, 1992.

[40] J.-D. Yau, Y.-B. Yang, and S.-R. Kuo, "Impact response of high speed rail bridges and riding comfort of rail cars," Engineering Structures, vol. 21, no. 9, pp. 836-844, 1999.

[41] C. Jiang and Z. M. Lin, "Test and research on the ballast-free track structure for high-speed railway," Chinese Railways, vol. 7, pp. 22-24, 2000 (Chinese).

[42] E. S. Hwang and A. S. Nowak, "Simulation of dynamic load for bridges," ASCE Journal of Structural Engineering, vol. 117, no. 5, pp. 1413-1434, 1991.

[43] F. Yang and G. A. Fonder, "An iterative solution method for dynamic response of bridge-vehicles systems," Earthquake Engineering \& Structural Dynamics, vol. 25, no. 2, pp. 195-215, 1996.

[44] L. K. Chen, Seismic responses of high-speed railway trainballastless track-bridge system and train-running safety during earthquake [Ph.D. thesis], Central South University, Changsha, China, 2012, (Chinese).

[45] L. K. Chen, L. Z. Jiang, and P. Liu, "Seismic response analyses of high-speed railway bridge round-ended piers using global bridge model," International Journal of Materials and Product Technology, vol. 44, no. 1-2, pp. 35-46, 2012.

[46] Q. Fu and C. Menun, "Seismic-environment-based simulation of near-fault ground motions," in Proceedings of the 13th World Conference on Earthquake Engineering, Vancouver, Canada, 2004.
[47] S. Akkar, U. Yazgan, and P. Gülkan, "Drift estimates in frame buildings subjected to near-fault ground motions," Journal of Structural Engineering, vol. 131, no. 7, pp. 1014-1024, 2005.

[48] J. W. Baker, "Quantitative classification of near-fault ground motions using wavelet analysis," Bulletin of the Seismological Society of America, vol. 97, no. 5, pp. 1486-1501, 2007.

[49] F. Mazza and A. Vulcano, "Effects of near-fault ground motions on the nonlinear dynamic response of base-isolated r.c. framed buildings," Earthquake Engineering \& Structural Dynamics, vol. 41, no. 2, pp. 211-232, 2012.

[50] Federal Emergency Management Agency, NEHRP Recommended Provisions for Seismic Regulations for New Buildings and Other Structures, FEMA 450, FEMA, Washington, DC, USA, 2003.

[51] B. Alavi and H. Krawinkler, "Effects of near-fault ground motions on frame structures," John A. Blume Earthquake Engineering Center Report 138, Stanford University, 2001.

[52] Pacific Earthquake Engineering Center (PEER), "PEER Strong Ground Motion Database," http://peer.berkeley.edu/products/ strong_ground_motion_db.html.

[53] E. Kalkan and S. K. Kunnath, "Effects of fling step and forward directivity on seismic response of buildings," Earthquake Spectra, vol. 22, no. 2, pp. 367-390, 2006.

[54] A. J. Papazoglou and A. S. Elnashai, "Analytical and field evidence of the damaging effect of vertical earthquake ground motion," Earthquake Engineering \& Structural Dynamics, vol. 25, no. 10, pp. 1109-1137, 1996.

[55] D. Benedetti and P. Carydis, "Influence of the vertical component on damage during shallow-near field earthquakes," European Earthquake Engineering, vol. 3, pp. 3-12, 1999.

[56] F. Mazza and A. Vulcano, "Nonlinear dynamic response of r.c. framed structures subjected to near-fault ground motions," Bulletin of Earthquake Engineering, vol. 8, no. 6, pp. 1331-1350, 2010.

[57] F. Mollaioli, A. Lucchini, Y. Cheng, and G. Monti, "Cheng and G. Monti, Intensity measures for the seismic response prediction of base-isolated buildings," Bulletin of Earthquake Engineering, vol. 11, no. 5, pp. 1841-1866, 2013.

[58] GB 50011-2001, Code for Seismic Design of Building, China Architecture and Building Press, Beijing, China, 2008, (Chinese).

[59] GB 50011-2010, Code for Seismic Design of Buildings, China Building Industry Press, Beijing, China, 2010, (Chinese).

[60] FEMA-356, Prestandard and Commentary for Seismic Rehabilitation of Buildings, Federal Emergency Management Agency, Washington, DC, USA, 2000.

[61] J. Zheng, "Key technologies for high-speed railway bridge construction," Engineering Science, vol. 10, no. 7, pp. 18-27, 2008 (Chinese).

[62] Temporary Provisions of Newly-Built 300-350km/H Passenger Special Railway Bridge Design[S], China Railway Press, Beijing, China, 2007, (Chinese).

[63] C. B. Chadwell, UCFYBER: Cross Section Analysis Structural Software, Department of Civil and Environmental Engineering, University of California, Berkeley, Calif, USA, 1999.

[64] J. Mander, M. Priestley, and R. Park, "Theoretical stressstrain model for confined concrete," ASCE Journal of Structural Engineering, vol. 114, no. 8, pp. 1804-1826, 1988.

[65] FEMA, "Quantification of building seismic performance factors," FEMA P695, Applied Technology Council for the Federal Emergency Management Agency, Washington, DC, USA, 2009. 
[66] ASCE, "Minimum design loads for buildings and other structures," ASCE/SEI 7-05, American Society of Civil Engineers, Reston, Va, USA, 2006.

[67] N. M. Newmark, J. A. Blume, and K. K. Kapur, "Seismic design spectra for nuclear power plants," ASCE Journal of the Power Division, vol. 99, no. 2, pp. 287-303, 1973.

[68] A. S. Elnashai and A. J. Papazoglou, "Vertical earthquake ground motion: evidence, effects and simplified analysis procedures," ESEE 95-06, Civil Engineering Department, Imperial College, London, UK, 1995. 

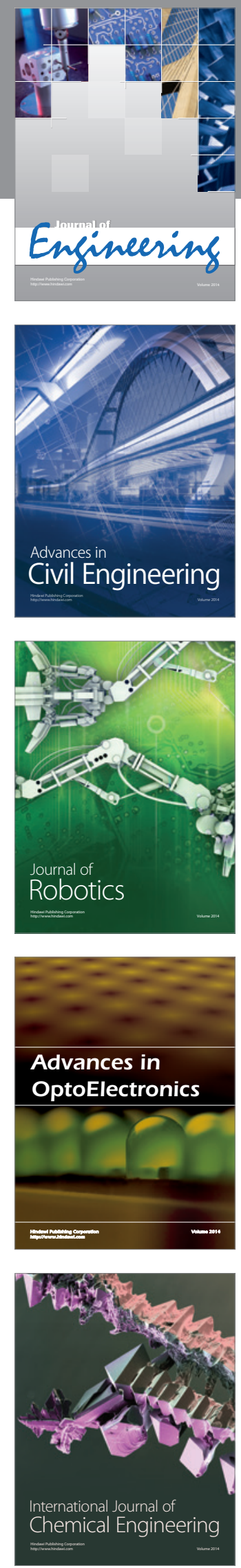

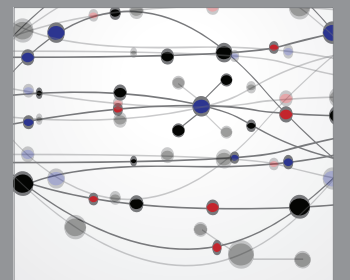

The Scientific World Journal
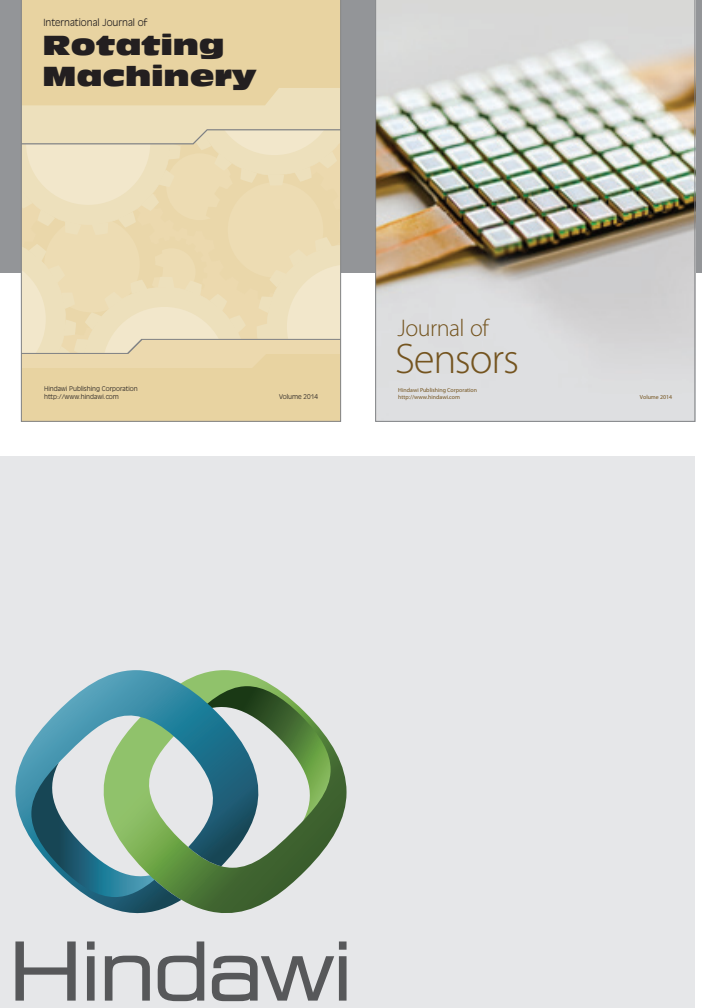

Submit your manuscripts at http://www.hindawi.com
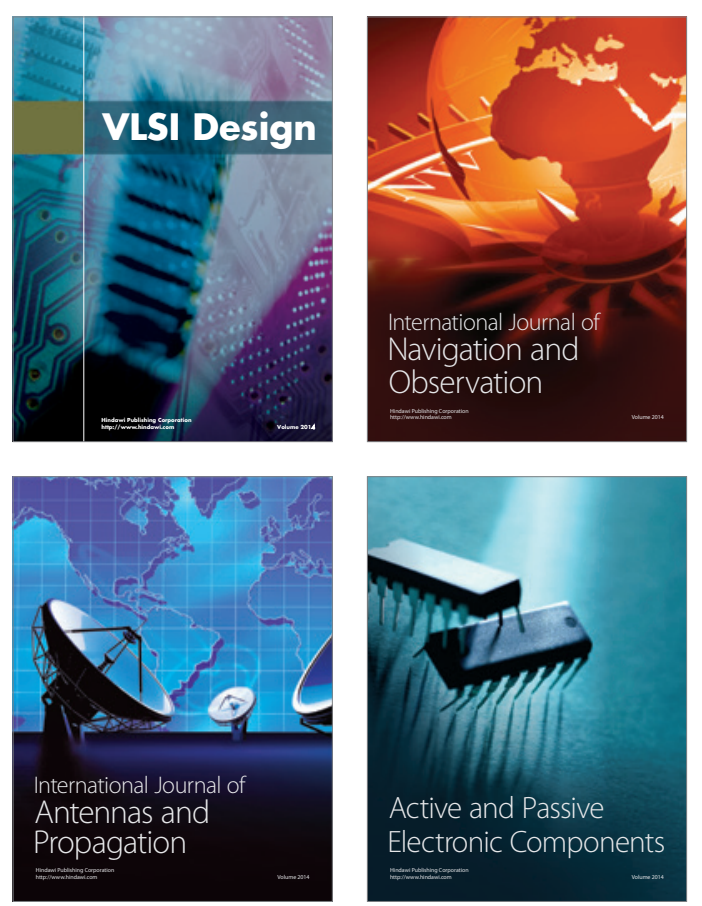
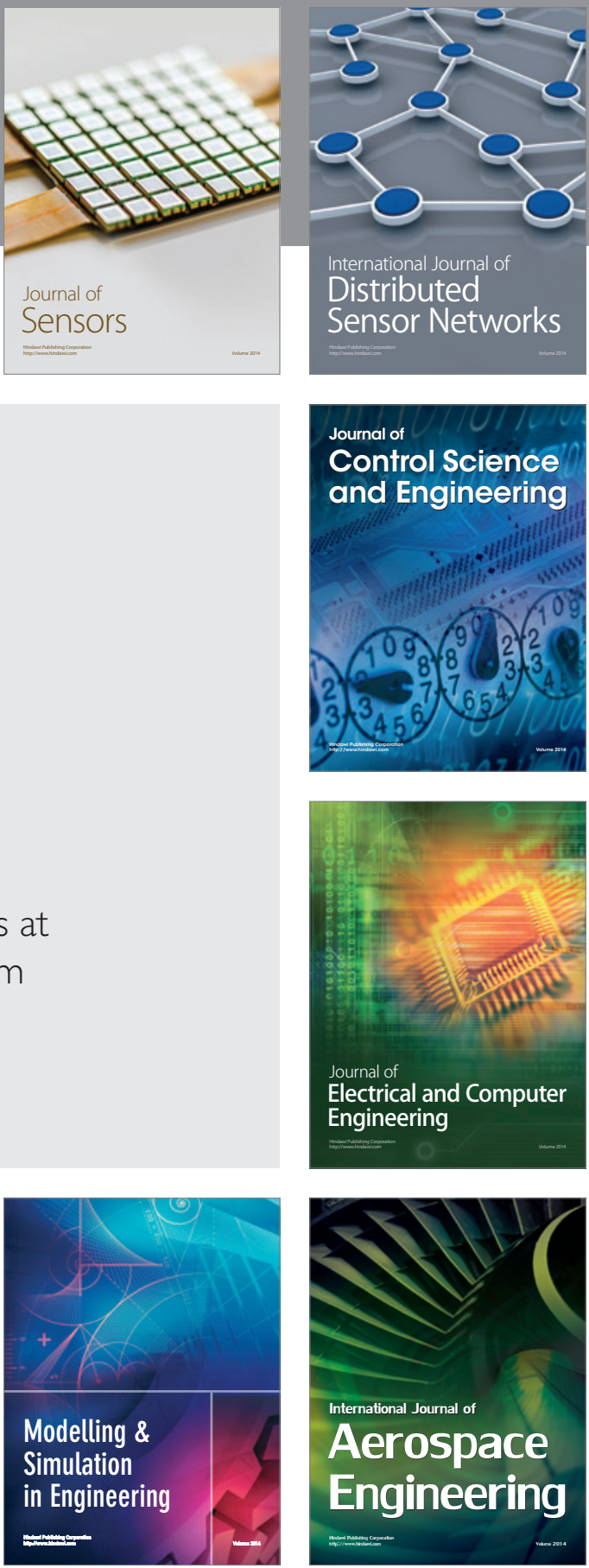

Journal of

Control Science

and Engineering
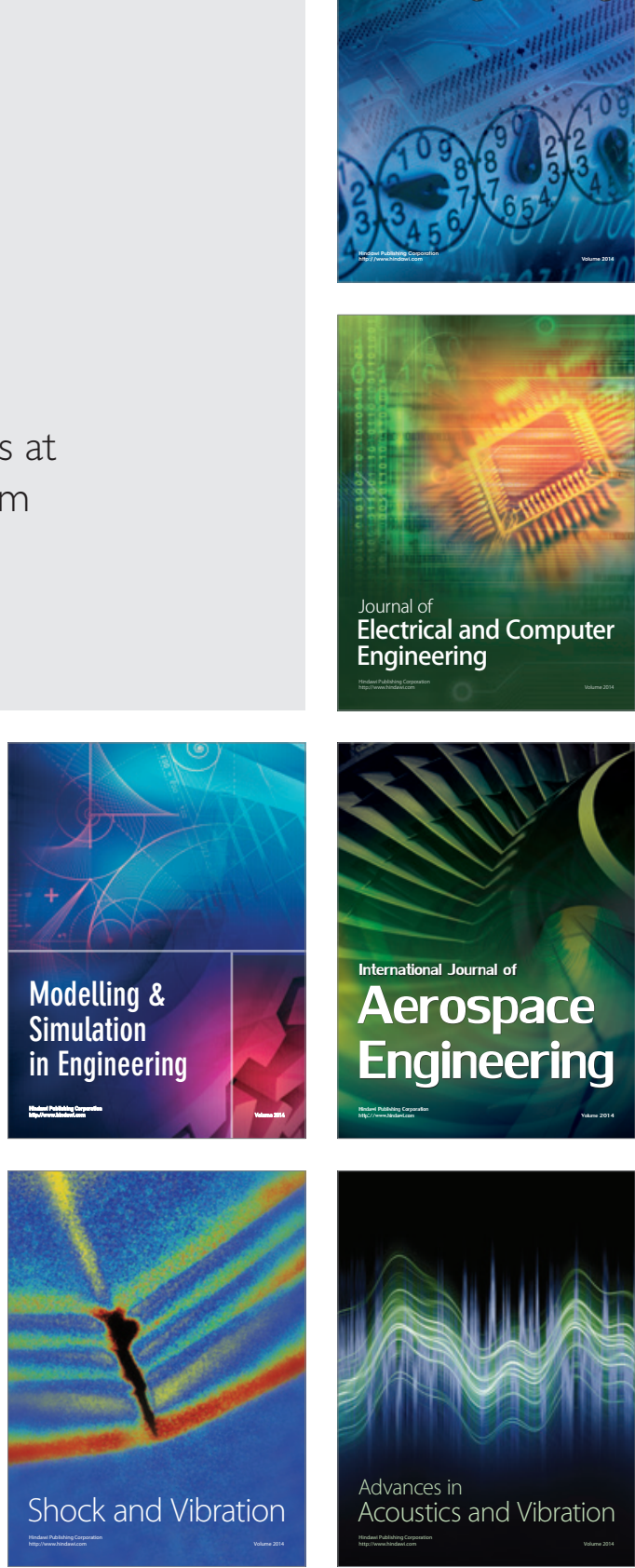